\title{
The Impact of Cost Strategy Policies on Company Performance in the Construction Industry in Brazil
}

Nathalie da Silva Cavalcanti ${ }^{1}$, Federal Technological University of Paraná, Paraná, Brazil

Cezar Augusto Romano², Federal Technological University of Paraná, Paraná, Brazil

\section{RESUMO}

Objetivo - Este artigo tem como objetivo avaliar a influência das políticas de estratégia de custo no desempenho de micro, pequenas e médias empresas do setor de construção civil em Curitiba e Região Metropolitana (sul do Brasil).

Desenho / metodologia / abordagem - Por meio de um questionário, a pesquisa coletou dados de 95 empresas. Os dados foram analisados com base em estatística descritiva e análise multivariada por meio da análise discriminante.

Resultados - Apontou-se que a falta de um processo estratégico é mais evidente nas empresas classificadas como empresas de baixo a médio desempenho. Com os dados, verifica-se que apenas $36 \%$ das empresas estão posicionadas para apenas uma das estratégias de posicionamento. A variável de estratégia de custo que teve o maior impacto no desempenho foi a política de "maior simplificação/padronização de produtos/serviços" em comparação com as demais variáveis analisadas no estudo.

Originalidade / valor - Os resultados implicam que a maioria das empresas não tem posicionamento estratégico e que é possível obter melhor desempenho por meio da gestão estratégica, incentivando o desenvolvimento dessa perspectiva nas empresas do setor.

Palavras-chave - Indústria da Construção; Estratégia; Gestão Estratégica; Estratégia de Custo; Survey.

\section{ABSTRACT}

Purpose- This article aims to assess the influence of cost strategy policies on the performance of sole traders, small and medium-sized companies in the civil construction sector in Curitiba and the Metropolitan Region (southern Brazil).

Design/methodology/approach - Using a questionnaire, the survey collected data from 95 companies. The data has been analyzed based on descriptive statistics and multivariate analysis using discriminant analysis.

Findings-Results showed that a lack of a strategic process is more evident in companies classified as low to medium performance companies. Only 36\% of companies are positioned for only one of the positioning strategies. The cost strategy variable, which had the greatest impact on performance, was the policy with "greater simplification/standardization of products/services" compared to the other variables analyzed in the study.

Originality/value - Results imply that most companies do not have a strategic position and that it is possible to obtain better performance through strategic management, encouraging the development of this perspective in companies in the sector.

Keywords - Construction Industry; Strategy; Strategic management; Cost strategy; Survey.

1.Av. Sete de Setembro, 3165 - Rebouças CEP 80230-901 - Curitiba - PR - Brasil, nathalie.cavalcanti@yahoo.com.br; https://orcid.org/0000-0003-0376-1027; 2. caromano@utfpr.edu.br; https://orcid.org/0000-0001-5479-3921

CAVALCANTI, N.S.; ROMANO, C.A. The Impact of Cost Strategy Policies on Company Performance in the Construction Industry in Brazil. GEPROS. Gestão da Produção, Operações e Sistemas, v.16, n 2, p. 88 - 121, 2021.

DOI: http://dx.doi.org/10.15675/gepros.v16i2.2749 


\section{INTRODUCTION}

Research relating strategy and construction from 2000 to 2011 published in periodicals and events in Brazil analyzed by Almeida et al. (2012) suggest that all analyzed companies have strategies, but many of them without necessarily a formal definition process. Most of the research has been qualitative through a case study with an interview and confirms that research in strategy in civil construction is still incipient, a fact also pointed out by Costa, Vieira and Barros-Neto (2010).

The concern of getting the next project may have denied the construction industry the strategic thinking for the future. The lack of strategic thinking is further exacerbated by the prevalence of small construction companies in the sector (SOETANTO; DAINTY, 2009). However, there is evidence that corporate values and strategy are important internal factors in determining the performance of construction companies with a positive impact on the growth of these companies (MAHMOOD et al., 2017; ZAIDI et al., 2018; OYEWOBI, WINDAPO and ROTIMI, 2017).

Versatility in a complex and dynamic world becomes a competitive differential and guarantees advantages in the sector for leaders connected with market dynamics. In the past there has been a lot of optimism in the civil construction area with few management studies and little concern in formalizing strategic processes. However, the global financial crisis and other market conditions have indicated fluctuations in the economy influencing business in civil construction in Brazil. Thus, given the importance of this issue in the global context, the relevance of deepening the theme of strategic management in companies in the construction industry is highlighted. This article aims to analyze the influence of cost strategy policies within micro, small and medium-sized construction companies in Curitiba and the Metropolitan Region of Curitiba (RMC), whose activities are construction, renovations and/or maintenance for residential, commercial or industrial uses; infrastructure work and specialized services; measured by the research variables and analyzed using descriptive and multivariate statistical analysis. This work contributes to emphasize the importance of implementing strategic solutions to obtain a management that can deal with the adversities of the sector and the economy, increasing the growth potential of companies. 


\section{THEORETICAL FOUNDATION}

\subsection{Civil Construction Scenario}

The construction industry is an important sector for the Brazilian economy, which, according to the Classificação Nacional de Atividades Econômicas (CNAE 2.0), comprises the following subsectors: construction of buildings, infrastructure works and specialized services for construction (IBGE, 2016).

Before the pandemic, the Brazilian economic scenario already had political uncertainties, reduced confidence, economic recession, increased unemployment and inflation (CBIC, 2016; IBRE, 2018a, 2018b). For the second half of 2020 and early 2021, a very gradual recovery is expected, with devastating effects on the labor market (rising unemployment) and reduced incomes. In addition to the health and economic crisis, Brazil faces a political crisis, being one of the emerging countries that has been most affected by the pandemic and political uncertainties (IBRE, 2020). These factors will slow down the recovery of the economy. Thus, the search for better results in both the short and long term becomes increasingly significant.

Faced with the presented scenario of credit reduction, drop in production, rising unemployment, the construction industry is going through a period of recession, as well as other sectors of the economy, needing more and more competent management to deal with the sector and the economy adversities.

\subsection{Strategy}

In the 1980s, the term competitive strategy was introduced by Porter, focusing on the knowledge of competition importance and how the relationship of market competition works for the development of strategy. The definition of the five forces allowed to structure and capture the differences between sectors and companies, bringing the concept of competitive advantage (PORTER, 1986). At that time, strategy was defined as the combination that the company makes between internal resources and skills, opportunities and risks created by the external environment (GRANT, 1991). 
Strategy can also be a plan, a pattern of behavior over the years (MINTZBERG, 2004, p. 34) or defined as an art of applying both available means and exploring favorable conditions to achieve specific results (FERREIRA, 2009).

Porter (1986, p. 49) states that there are three generic strategies to achieve aboveaverage performance in the industry: cost leadership, differentiation and focus. Emphasizes the choice of strategic positioning between cost advantage and differentiation, and between large or small scope for the company to obtain a competitive advantage. Therewith, a favorable position is sought to establish a profitable and sustainable position against the competitive forces of the market. The choice of any of these strategies requires total commitment that can be diluted if there are more than one primary target, resulting in a poor strategy with reduced profitability chances.

The company that manages to sustain this leadership becomes the lowest cost producer in the industry. In the differentiation leadership, the company seeks to be the only one in the industry, having uniqueness and being able to demand higher prices for this status. It implies that the company's attributes are different from rivals and creates consumer loyalty (PORTER, 1986, p. 49).

Mahmood et al. (2017), analyzing 255 small construction companies in Malaysia using questionnaires and descriptive analysis and multiple regression have concluded that there is evidence that business values and strategy are important internal factors in determining a company's performance, in addition to others organizational factors. Oyewobi, Windapo and Rotimi (2017) reach the same conclusion by evaluating 72 large companies in South Africa using structural equations of partial least squares. Likewise, Zaidi et al. (2018) attest through Spearman's correlation with 25 questionnaires in the construction sector in Malaysia that the strategy implementation is strongly correlated with the company's performance.

The study by Ho (2016) finds, through analysis of 130 companies in the construction industry in Hong Kong, that the low-cost strategy performs better when there is strong rivalry with high-bargain customers and little threat of new entrants. The author characterizes this scenario as the competitive scenario of this sector. Tansey, Meng and Cleland (2013), through pilot case studies in Ireland and England, show that cost leadership strategies have been often used in the 2007 recession. 
Chinowsky and Meredith (2000) and Arif, Azhar and Bayraktar (2012) propose strategic management and basic aspects to contribute to the construction industry. Maia (2014) analyzes organizational characteristics and the level of effectiveness of the sector's processes. El-Hallaq and Tayeh (2015) discuss factors of strategic planning. Some authors recognize that most studies focus on the analysis of strategic positioning adopted by companies, but little attention is paid to how this strategic positioning is defined and which strategic practices are adopted by companies. It is possible, as pointed out in the research, that some companies have implicit strategies without the formal strategic process, implying a strategic choice with little reasoning and analysis. Based on these hypotheses, this study seeks to understand the strategic management of companies in Curitiba and RMC.

\section{METHODOLOGICAL PROCEDURES}

The present work can be classified as an applied purpose, a quantitative approach (GIL, 2010, p.26) and a descriptive objective (KÖCHE, 2015, p. 124). The data collection method is classified as a survey, cross-sectional development (VIEIRA, 2009) with multivariate analysis statistical treatment, according to the steps shown in Figure 1.

\subsection{Survey Planning}

For the questionnaire elaboration, the analysis of the publications obtained in the literature review, theoretical framework and other sources of study have been taken into consideration. Thus, based on the information obtained from the work of Chinowsky and Meredith (2000), Arif, Azhar and Bayraktar (2012), Maia (2014), El-Hallaq and Tayeh (2015) and Porter (1986), the relationships between variables has been defined (dependence or independence), their groupings and constructs.

Construct is the definition of a concept elaborated in the light of theories with unique meaning and can be accepted by the entire scientific community (KÖCHE, 2015, p. 33). Independent variables influence and affect dependent variables. The dependent variables are result and consequence, seeking their explanation as the researcher changes the independent variable (LAKATOS; MARCONI, 2017). That said, the variables have been divided into two groups: independent (18 variables), and dependent (7 variables), resulting in 25 variables. 
Figure 1 - Research methodology steps

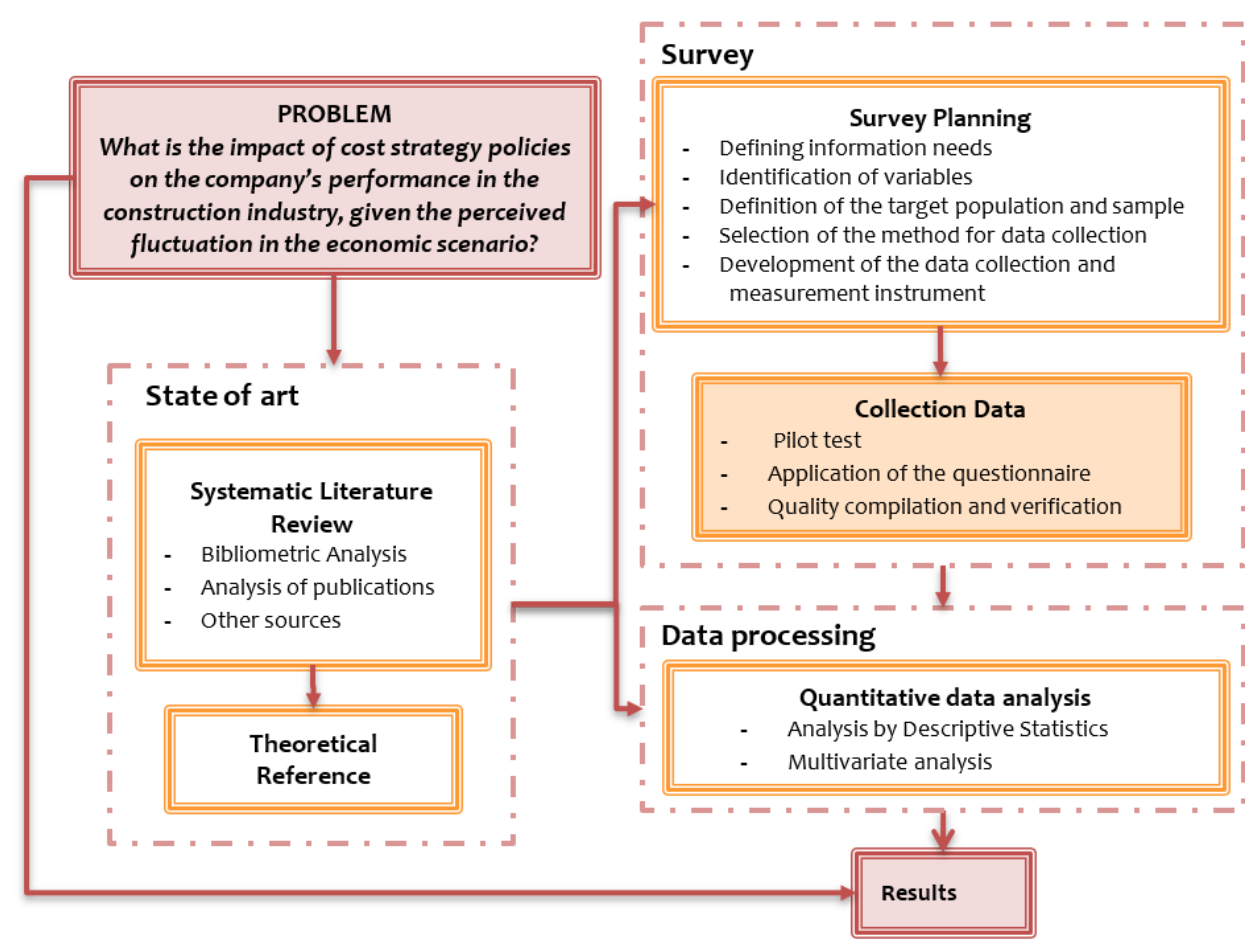

Source: Author (2020).

Table 1 shows the group, constructs, questions related to the questionnaire and the variables. For independent variables, 2 factors or constructs based on Porter (1986): the variables of strategic positioning and variables related to cost strategies.

Table 1 - Strategy-independent variables

\begin{tabular}{|c|c|c|c|}
\hline Group & Constructs & Questions & Variables \\
\hline \multirow{17}{*}{ 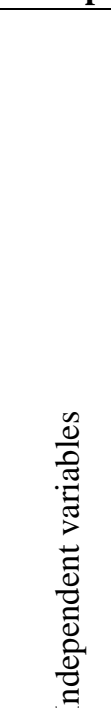 } & \multirow{3}{*}{$\begin{array}{l}\text { Positioning } \\
\text { (3 variables) }\end{array}$} & \multirow{3}{*}{$\begin{array}{l}15,16 \text { and } \\
17\end{array}$} & Leadership in differentiating your products \\
\hline & & & Market cost leadership \\
\hline & & & Focus strategy \\
\hline & \multirow{14}{*}{$\begin{array}{l}\text { Cost Strategy } \\
\text { Features } \\
\text { (15 variables) }\end{array}$} & \multirow{14}{*}{$\begin{array}{lrr}41 \text { to } & 54 \\
\text { and } 65\end{array}$} & Vigorous pursuit of cost reductions \\
\hline & & & Strict control of costs and overheads \\
\hline & & & Investment in $R \& D$, assistance, sales force and advertising \\
\hline & & & Cost of products or services in relation to competitors \\
\hline & & & Differentiated access to raw materials \\
\hline & & & Simplification / standardization of products / services \\
\hline & & & Frequent and detailed control reports \\
\hline & & & Structured management, roles and responsibilities \\
\hline & & & Continuous capital investment \\
\hline & & & Access to capital (own / third parties) \\
\hline & & & Process engineering skills \\
\hline & & & Intense supervision of the workforce \\
\hline & & & Aggressively launch products / services on a scale \\
\hline & & & Reward for quantitative goals \\
\hline
\end{tabular}


For the dependent variables, 7 variables through 4 constructs (variables related to financial results, human resources, effectiveness of strategic processes and flexibility to adapt changes), based on the authors listed in Table 2 .

To define the target population of the study, business segments follows CNAE (IBGE, 2007), the segments of Section F (Construction):

- Division 41 - Building construction class 41.20-4;

- Division 42 - Infrastructure work;

- Division 43 - Specialized services.

Table 2 - Dependent variables related to the strategy

\begin{tabular}{|c|c|c|c|c|}
\hline Group & Constructs & Sources & Questions & Variables \\
\hline \multirow{5}{*}{ 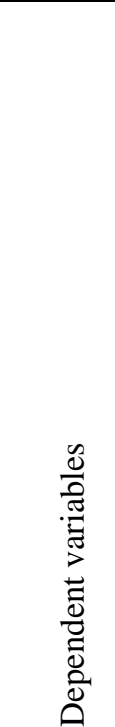 } & \multirow{2}{*}{$\begin{array}{l}\text { Financial } \\
\text { result } \\
\text { (2 variables) }\end{array}$} & \multirow[b]{2}{*}{ Maia (2014) } & \multirow[b]{2}{*}{38 and 39} & Average business profitability over the past two years \\
\hline & & & & Company growth rate in the last two years \\
\hline & $\begin{array}{l}\text { Human } \\
\text { Resources } \\
\text { (2 variables) }\end{array}$ & $\begin{array}{l}\text { Arif, Azhar and } \\
\text { Bayraktar } \\
(2012), \text { El-Hallaq } \\
\text { and } \\
(2015)\end{array}$ & 32 and 37 & Employee turnover \\
\hline & $\begin{array}{l}\text { Effectiveness } \\
\text { (2 variables) }\end{array}$ & $\begin{array}{l}\text { Arif, Azhar and } \\
\text { Bayraktar } \\
(2012) \text {, El-Hallaq } \\
\text { and Tayeh } \\
(2015) \text {, } \\
\text { Chinowsky and } \\
\text { Meredith (2000) }\end{array}$ & 18 and 34 & Cooperation of employees according to the strategy \\
\hline & $\begin{array}{l}\text { Flexibility } \\
\text { (1 variable) }\end{array}$ & $\begin{array}{l}\text { El-Hallaq and } \\
\text { Tayeh (2015), } \\
\text { Maia (2014) }\end{array}$ & 74 & Effectiveness of implementing strategies \\
\hline
\end{tabular}

For the size of the companies, the classification considers the annual gross operating revenue of the National Development Bank (BNDES, 2017):

- $\quad$ MICRO - Up to R 360 thousand;

- SMALL - Greater than R\$ 360 thousand and less than or equal to R\$3.6 million;

- AVERAGE - Greater than R $\$ 3.6$ million and less than or equal to $\mathrm{R} \$ 300$ million.

For the company profile, multiple choice and discursive questions has been developed to characterize the company. The questions have considered the company's founding year, operation region, number of own employees and outsourced employees, type of constitution and type of administration, number of certifications, the president profile, company size, field 
of activity, number of projects already executed and in progress. Regarding the company name, this information is kept confidential and has been reported as non-mandatory questions to be filled out. For the interviewee's profile, information has been requested about the position and area, company time and training area.

For questions related to strategic management, classified as closed, the seven-level semantic differential scale (VIEIRA, 2009) has been the selected scale, as shown in Table 3. This type of question fits into a metric scale often called quantitative (HAIR JR et al., 2005a, p. 157-189).

Table 3 - Semantic differential scale example

\begin{tabular}{|c|c|c|c|c|c|c|c|c|c|}
\hline \multicolumn{2}{|r|}{ Question } & \multicolumn{8}{|l|}{ Scale } \\
\hline 1 & $\begin{array}{l}\text { Does the company have a clearly } \\
\text { defined vision, mission and values? }\end{array}$ & Nonexistent & & & & & & $5 \mid 7$ & Clearly defined \\
\hline 2 & Is there an annual strategic plan? & Non-existent process & 1 & 2 & & & & 67 & \begin{tabular}{|lr} 
Process & ful \\
implemented \\
working
\end{tabular} \\
\hline 3 & Are most strategies implemented? & None is implemented & 1 & 2 & 3 & & & 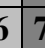 & Most are implemented \\
\hline
\end{tabular}

Source: Author (2020).

This metric scale of semantic differential uses final bipolar points (or anchors), chosen to describe opposite adjectives or adverbs, with intermediate points typically numbered. Despite being easy to understand metric scales, it presents subjectivity depending on how the question is asked and the importance it has for the participants (SAMARTINI, 2006). Thus, the results cannot be considered absolute, but seen as trends.

\subsection{Pilot Test}

A pilot test has been applied with nine companies from the defined target population, allowing a global analysis of the questionnaire, identifying the respondents' doubts and coherence of the answers before the questionnaire final application.

\subsection{Collecting Data}

After readjusting the questionnaire in the pilot test, the effective data collection phase began in March 2018. The collection phase lasted 6 months ending in August 2018. The research uses the non-probabilistic sampling method for convenience, in which involves selecting the most accessible samples to obtain the necessary information (HAIR JR. et al., 
2005a, p. 247). Of the total of companies invited to participate in the survey, 95 have answered the questionnaire, of which 23 companies has been classified as micro, 39 small companies and 33 medium-sized companies. Approximately $97 \%$ of the sample has been obtained using the electronic form of the Google tool and the other $3 \%$ in person using paper.

\subsection{Data preparation}

The company's performance has been classified by the answer to the questions in Table 4, which considers the variables dependent on the study and the amount of certification that the company has. It takes into account the concepts of work performance indicators by Kaplan and Norton (1997); Santos, Paladini and Jungles (2014); Maciel and Cândido (2016); Chinowsky and Meredith (2000); Arif, Azhar and Bayraktar (2012); Maia (2014) and ElHallaq and Tayeh (2015).

Table 4 - Performance rating

\begin{tabular}{l|l|l|l|l} 
Question & Question & Range & Indicator & Scale \\
\hline Profile & $\begin{array}{l}\text { Does the company have any type of } \\
\text { program or certification? }\end{array}$ & Number of certifications & Quality \\
\hline 38 & $\begin{array}{l}\text { The average profitability of the } \\
\text { business over the past two years: }\end{array}$ & $\begin{array}{l}\text { Between "None" and "Very high } \\
(>20 \%) "\end{array}$ & $\begin{array}{l}\text { Financial } \\
\text { results }\end{array}$ & 1 to 7 \\
\hline 39 & $\begin{array}{l}\text { The company's growth rate over the } \\
\text { past two years: }\end{array}$ & $\begin{array}{l}\text { Between "Zero" and "Very high } \\
(>20 \%) "\end{array}$ & $\begin{array}{l}\text { Financial } \\
\text { results }\end{array}$ & 1 to 7 \\
\hline 37 & $\begin{array}{l}\text { What is the level of employee } \\
\text { turnover? }\end{array}$ & $\begin{array}{l}\text { Between "High" and "Low" } \\
\text { Resources }\end{array}$ & 1 to 7 \\
\hline 32 & $\begin{array}{l}\text { Do employees work as a team in } \\
\text { pursuit of the strategy's realization? }\end{array}$ & $\begin{array}{l}\text { Between "Work individually" } \\
\text { and "Work as a team" }\end{array}$ & $\begin{array}{l}\text { Human } \\
\text { Resources }\end{array}$ & 1 to 7 \\
\hline 18 & $\begin{array}{l}\text { Are most strategies implemented? } \\
\text { How present are the strategic } \\
\text { and "Most are implemented" } \\
\text { decisions? }\end{array}$ & $\begin{array}{l}\text { Between "Little or nothing } \\
\text { present" and "Extremely } \\
\text { present" }\end{array}$ & Effectiveness & 1 to 7 \\
\hline 74 & $\begin{array}{l}\text { Does the company have the flexibility } \\
\text { to adapt to changes in the environment? }\end{array}$ & $\begin{array}{l}\text { Between "Little flexibility" and } \\
\text { "High flexibility" Flexibility }\end{array}$ & 1 to 7 \\
\hline
\end{tabular}
Source: Author (2020).

The sum of the answers to the performance questions, separates the companies into two groups, as shown in Table 5. This data transformation through the sum of variables is a process of modifying the original data to create new ideas (HAIR JR et al., 2005a, p. 261). 
Table 5 - Performance of companies

\begin{tabular}{lll}
\hline Punctuation & Quantity & Performance \\
\hline From 16 to 29 & 45 & Low to Medium Performance \\
From 30 to 49 & 50 & Medium to High Performance \\
\hline Total & 95 & \\
\hline \multicolumn{2}{c}{ Source: Author $(2020)}$.
\end{tabular}

\section{RESULTS}

In the research, 95 questionnaires have been analyzed. Most respondents work in organizations with 9 to 18 years of age, in which the main area of activity is construction, renovation and / or residential maintenance. For the gross annual revenue, the research presents balance between micro, small and medium samples, but small companies have greater representation. They have, in large part, family management and lack of investment in quality certification. In most cases, the president's professional background is engineering. The majority profile participants are directors and presidents with 6 to 20 years in the company.

\subsection{Descriptive analysis}

The second part of the questionnaire dedicates to answer questions related to positioning and cost strategy policies. The SPSS software makes it possible to analyze the frequency graph of each variable. The boxsplot compares the difference in the histogram curve between companies classified as low to medium performance (classification 1 in the boxsplot) and companies with medium to high performance (classification 2 in the boxsplot) for each variable.

Histogram is a graphical representation of the frequency of occurrences of each response category, making it possible to assess whether the curve approaches the normal distribution. Boxsplot is the box chart that represents the data distribution (HAIR JR et al., 2009, p. 53).

\subsubsection{Positioning}

In the "Positioning" construct, three questions have been asked, according to Table 6. 
Table 6 - Independent "Positioning" variables

\section{Positioning}

\begin{tabular}{|c|c|c|c|c|c|c|c|c|c|c|}
\hline 15 & $\begin{array}{l}\text { Does the company focus on } \\
\text { leading the uniqueness of its } \\
\text { products using policies of: } \\
\text { increasing the value of the } \\
\text { product for being } \\
\text { differentiated, investment in } \\
\text { marketing, creativity, } \\
\text { product development, etc.? }\end{array}$ & $\begin{array}{l}\text { Do not } \\
\text { have } \\
\text { these } \\
\text { policies }\end{array}$ & 1 & 2 & 3 & 4 & 5 & 6 & 7 & $\begin{array}{l}\text { Uses } \\
\text { heavily } \\
\text { on all } \\
\text { these } \\
\text { policies }\end{array}$ \\
\hline 16 & $\begin{array}{l}\text { Does the company focus on } \\
\text { market cost leadership using } \\
\text { policies such as: product } \\
\text { standardization, economies } \\
\text { of scale, cost advantage, } \\
\text { strict cost control, control } \\
\text { reports, etc.? }\end{array}$ & $\begin{array}{l}\text { Do not } \\
\text { have } \\
\text { these } \\
\text { policies }\end{array}$ & 1 & 2 & 3 & 4 & 5 & 6 & 7 & $\begin{array}{l}\text { Uses } \\
\text { heavily } \\
\text { on all } \\
\text { these } \\
\text { policies }\end{array}$ \\
\hline 17 & $\begin{array}{l}\text { Does the company use the } \\
\text { focus strategy (strategy } \\
\text { aimed at a specific niche in } \\
\text { the market)? }\end{array}$ & $\begin{array}{l}\text { Does } \\
\text { not use } \\
\text { focus } \\
\text { strategy }\end{array}$ & 1 & 2 & 3 & 4 & 5 & 6 & 7 & $\begin{array}{l}\text { Strongly } \\
\text { uses } \\
\text { focus } \\
\text { strategy }\end{array}$ \\
\hline
\end{tabular}

Source: Author (2020).

Of the 95 companies, only $18 \%$ focus heavily on differentiation, $18 \%$ focus heavily on cost, $25 \%$ have low use of both positioning strategies, $21 \%$ reported using both positioning strategies heavily and $18 \%$ reported intermediate responses. According to Porter's theory (1986), the company must position itself in only one of the generic strategies to achieve competitive advantage. Thus, the result implies that most companies do not have a unique strategic position.

As for the differentiation leadership, the histogram of focus on differentiation is not conclusive (Graph 1), however the boxsplot presents a great distance of behavior between organizations and their performance. This means that companies that report focusing on this strategy tend to perform better.

In the study by Oyewobi, Windapo and Rotimi (2013), with 16 companies in South Africa, it appears that most companies tend to use the differentiation strategy in a highly competitive complex market. In Maia's analysis (2014), it appears that the positioning process is under development in all sectors of civil construction analyzed in this study. 
Graph 1 - Histogram and boxsplot of singularity leadership
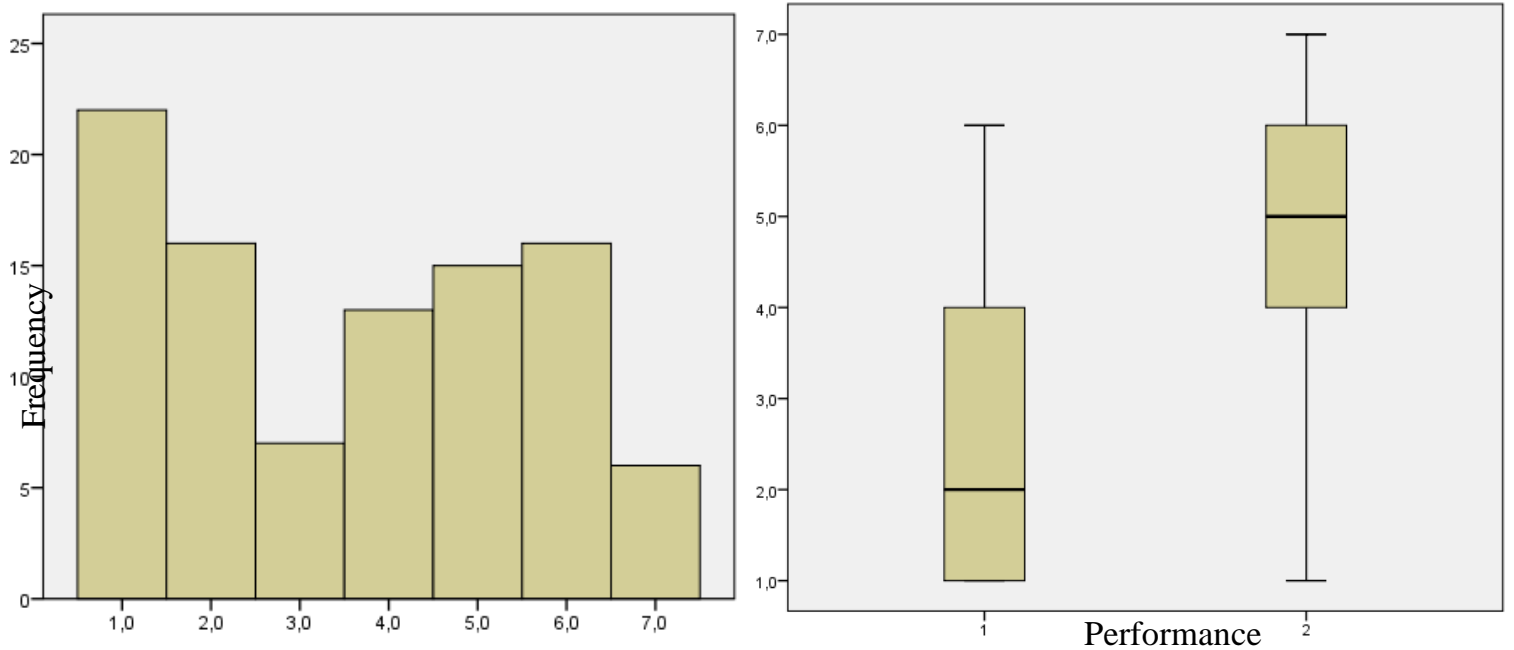

Source: Author (2020).

As for cost leadership, the histogram (Graph 2) does not present a trend as in the singularity leadership, due to the diversity of responses, but it presents a concentration of intermediate responses. Boxsplot has a slight relationship between better performance and cost leadership. This means that the company that has a focus on some strategy can generate better performance.

Graph 3 is shown for the focus strategy. The bar graph shows a certain tendency to exist a strategy for a niche market, due to the slight slope of the curve to the right. However, boxsplot shows little difference in results for different performances due to data dispersion for companies with lower performance.

Of the 95 organizations, 51 use a focus strategy (54\%), however 17 of these use a focus focused on both cost leadership and differentiation. According to Porter's theory (1986), the focus must be given either to cost leadership or to differentiation leadership. 
Graph 2 - Cost leadership histogram and boxsplot
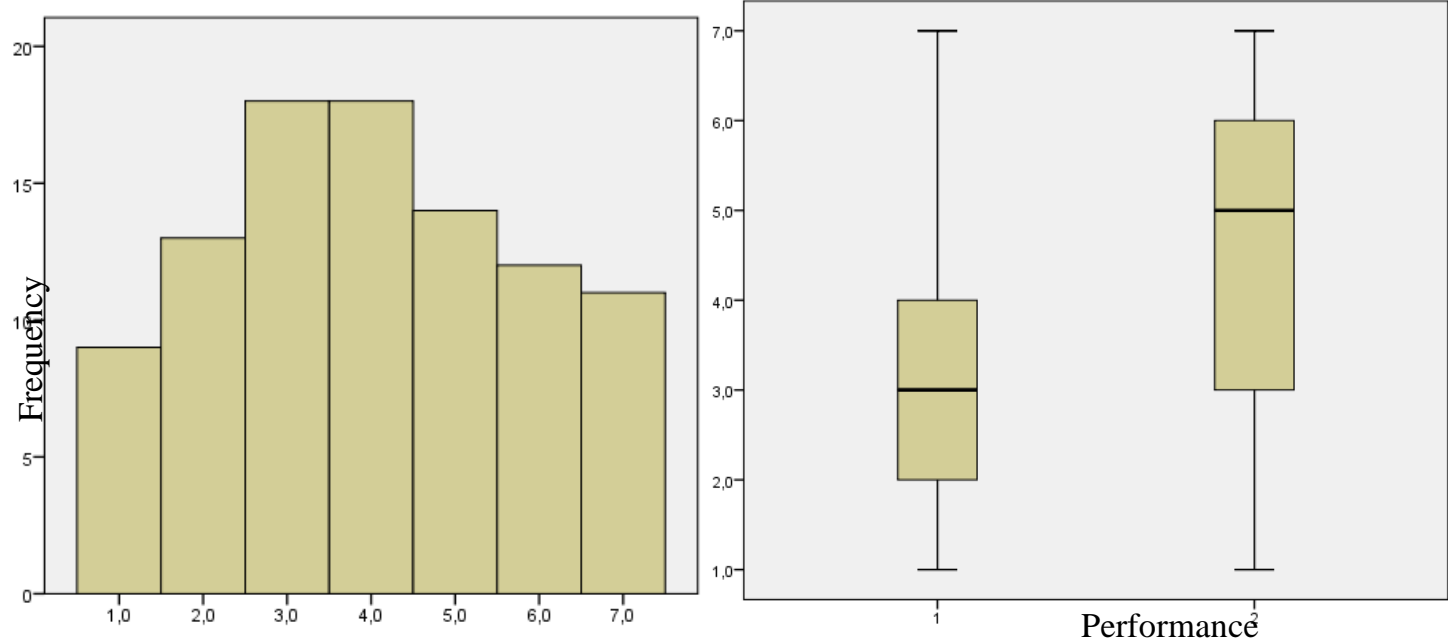

Source: Author (2020).

Graph 3 - Histogram and focus strategy boxsplot
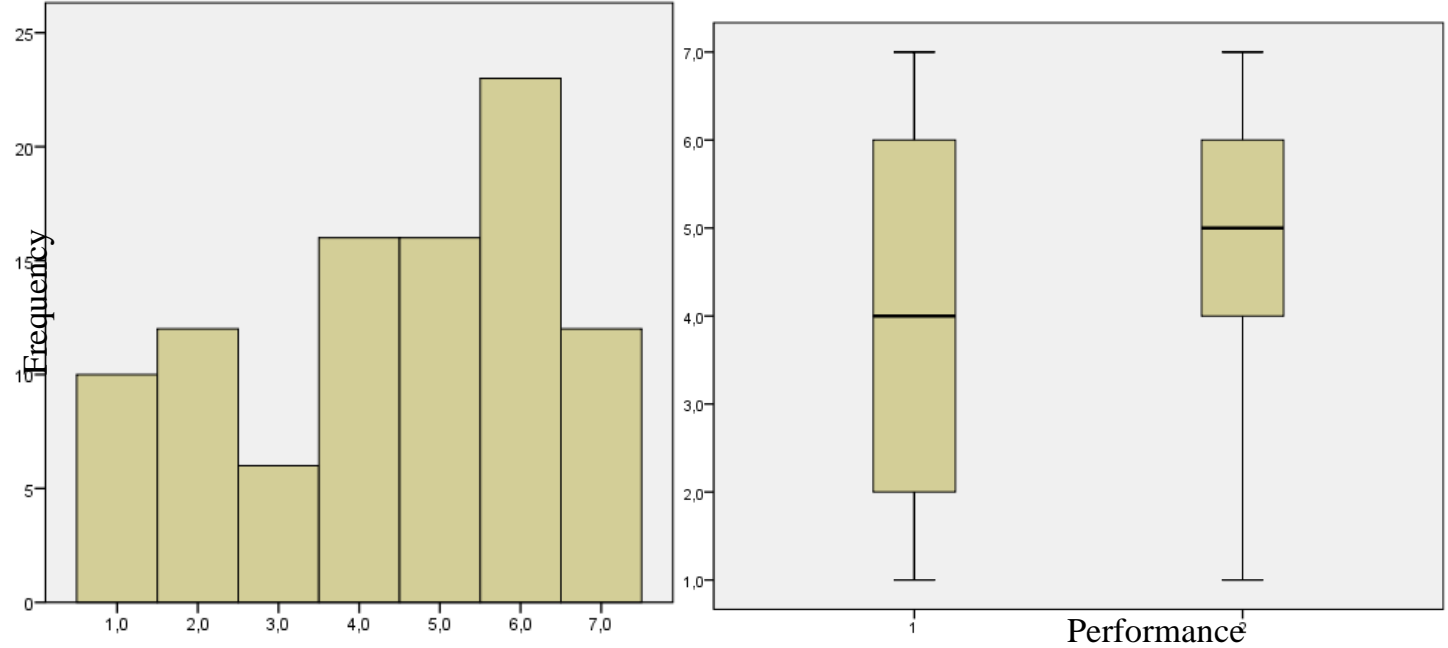

Source: Author (2020).

Analyzing the data, it appears that only $36 \%$ companies are positioned for only one of the strategies. Thus, the result implies that the rest of the companies do not have a unique strategic positioning, in line with studies by Maia (2014) and Chinowsky and Meredith (2000). For the construct "Positioning", the three generic strategies have been analyzed: leadership of differentiation, cost and focus, through descriptive statistics. As for the differentiation leadership, there is a gap in behavior between organizations and their performance, and the companies best positioned in this strategy are the ones that have the best performance. The same is seen in cost leadership, and the focus on cost is linked to better performance results. That is, focusing heavily on some leadership represents better results. However, for the focus strategy, aimed at a specific market niche, there is little difference in 
results for the different performances due to the dispersion of responses. Anyway, companies with lower performance tend to focus less on a niche market.

\subsubsection{Cost strategy characteristics}

In the construct "Cost Strategy Characteristics", fifteen questions have been asked, according to Table 7.

Table 7 - Independent variables of "Cost strategy characteristics"

\section{"Cost strategy characteristics"}

\begin{tabular}{|c|c|c|c|c|c|c|c|c|c|c|}
\hline 41 & $\begin{array}{l}\text { Is there vigorous pursuit of cost reductions } \\
\text { as the company gains market experience? }\end{array}$ & Low cost chase & 1 & 2 & 3 & 4 & 5 & 6 & 7 & High cost chase \\
\hline 42 & $\begin{array}{l}\text { Is there strict control over costs and } \\
\text { overheads? }\end{array}$ & $\begin{array}{l}\text { Little control over } \\
\text { costs and expenses }\end{array}$ & 1 & 2 & 3 & 4 & 5 & 6 & 7 & $\begin{array}{l}\text { Excessive control of } \\
\text { costs and expenses }\end{array}$ \\
\hline 43 & $\begin{array}{l}\text { How much of the budget is invested in } \\
\text { R\&D, assistance, sales force and } \\
\text { advertising? }\end{array}$ & Low investment & 1 & 2 & 3 & 4 & 5 & 6 & 7 & High investment \\
\hline 44 & $\begin{array}{l}\text { Does the company have a lower cost of } \\
\text { products or services compared to its } \\
\text { competitors? }\end{array}$ & No lower cost & 1 & 2 & 3 & 4 & 5 & 6 & 7 & It has lower cost \\
\hline 45 & $\begin{array}{l}\text { Do you have different access to raw } \\
\text { materials compared to your competitors? }\end{array}$ & $\begin{array}{l}\text { It does not have } \\
\text { differentiated } \\
\text { access }\end{array}$ & 1 & 2 & 3 & 4 & 5 & 6 & 7 & $\begin{array}{l}\text { Has differentiated } \\
\text { access }\end{array}$ \\
\hline 46 & $\begin{array}{l}\text { Is there a certain simplification / } \\
\text { standardization of products / services to } \\
\text { facilitate operation? }\end{array}$ & $\begin{array}{l}\text { No simplification / } \\
\text { standardization of } \\
\text { products }\end{array}$ & 1 & 2 & 3 & 4 & 5 & 6 & 7 & $\begin{array}{l}\text { High simplification / } \\
\text { standardization of } \\
\text { products }\end{array}$ \\
\hline 47 & $\begin{array}{l}\text { Do you have frequent and detailed control } \\
\text { reports? }\end{array}$ & No control reports & 1 & 2 & 3 & 4 & 5 & 6 & 7 & $\begin{array}{l}\text { Has frequent and } \\
\text { detailed control } \\
\text { reports }\end{array}$ \\
\hline 48 & $\begin{array}{l}\text { Does the company have a structured } \\
\text { management organization, functions and } \\
\text { responsibilities? }\end{array}$ & Low structuring & 1 & 2 & 3 & 4 & 5 & 6 & 7 & High structuring \\
\hline 49 & $\begin{array}{l}\text { Are the company's capital investments } \\
\text { continuous? }\end{array}$ & $\begin{array}{l}\text { Low continuous } \\
\text { investments }\end{array}$ & 1 & 2 & 3 & 4 & 5 & 6 & 7 & $\begin{array}{l}\text { Continuous } \\
\text { investments }\end{array}$ \\
\hline 50 & $\begin{array}{l}\text { Does the company have access to capital } \\
\text { (own / third parties)? }\end{array}$ & $\begin{array}{l}\text { Low access to } \\
\text { capital }\end{array}$ & 1 & 2 & 3 & 4 & 5 & 6 & 7 & $\begin{array}{l}\text { Strong access to } \\
\text { capital }\end{array}$ \\
\hline 51 & $\begin{array}{l}\text { Does the company use process engineering } \\
\text { skills? }\end{array}$ & Little use & 1 & 2 & 3 & 4 & 5 & 6 & 7 & Lots of use \\
\hline 52 & $\begin{array}{l}\text { Is there intense supervision of the } \\
\text { workforce? }\end{array}$ & Little supervision & 1 & 2 & 3 & 4 & 5 & 6 & 7 & Intense supervision \\
\hline 53 & $\begin{array}{l}\text { Does the company aggressively launch } \\
\text { products / services on an efficient scale? }\end{array}$ & Little aggressive & 1 & 2 & 3 & 4 & 5 & 6 & 7 & Quite aggressive \\
\hline 54 & $\begin{array}{l}\text { Are entrepreneurial attitudes and initiatives } \\
\text { encouraged and rewarded by quantitative } \\
\text { goals? }\end{array}$ & $\begin{array}{l}\text { No quantitative } \\
\text { targets }\end{array}$ & 1 & 2 & 3 & 4 & 5 & 6 & 7 & Quantitative goals \\
\hline 65 & $\begin{array}{l}\text { Does the company care about the cost of its } \\
\text { products or services in relation to its } \\
\text { competitors? }\end{array}$ & No worries & 1 & 2 & 3 & 4 & 5 & 6 & 7 & Much concern \\
\hline
\end{tabular}

Source: Author (2020) 


\subsubsection{Vigorous pursuit of cost reduction}

The existence of vigorous pursuit of cost reductions as the company acquires market experience is shown in Graph 4. It appears that it is a policy strongly followed by the survey respondents, both by the steep slope of the curve on the right in the histogram and by the medians presented in the boxsplot. In this case, there is little or no influence of performance on the result.

Graph 4 - Histogram and boxsplot of vigorous pursuit of cost reduction
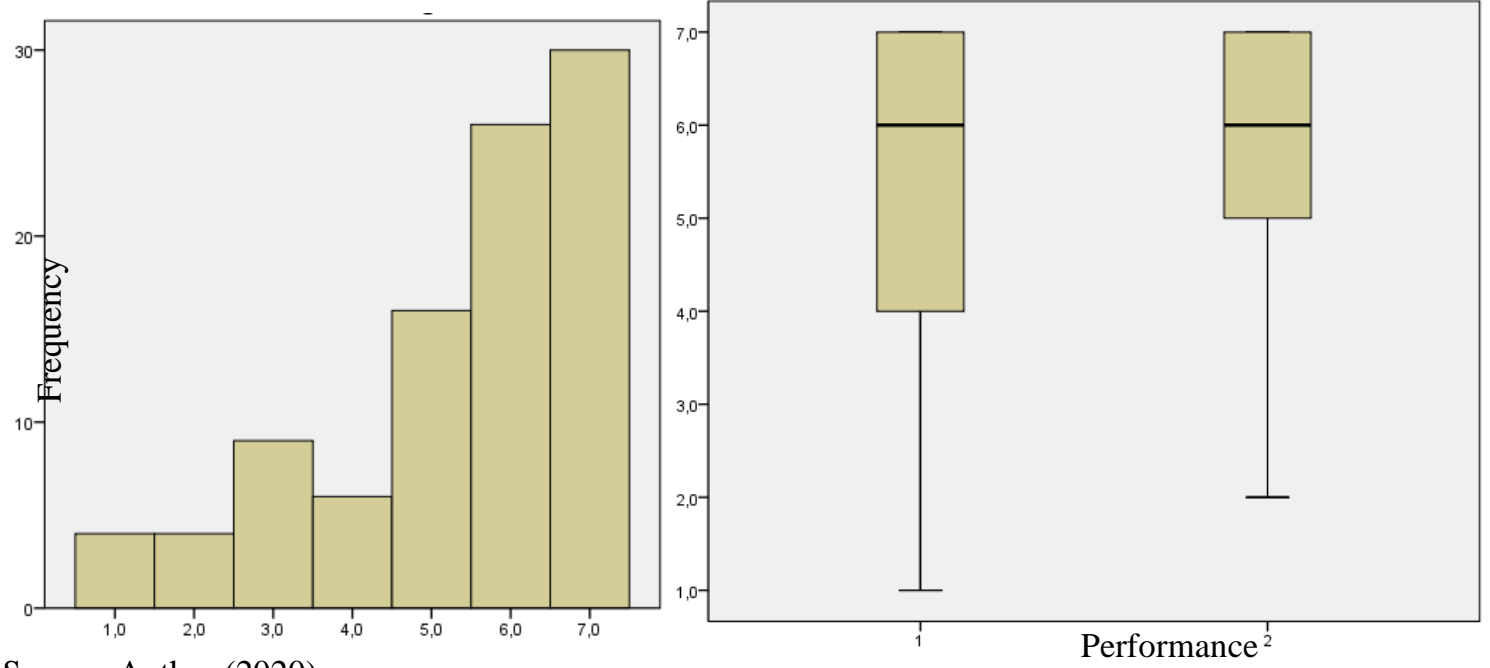

Source: Author (2020).

\subsubsection{Strict control of costs and expenses}

The policy of strict control of costs and expenses is observed in Graph 5. There is a strong slope of the curve to the right in the histogram as well as high medians in the boxsplot. This represents little or no influence of performance on results and strict control of costs and overheads by most organizations. 
Graph 5 - Histogram and boxsplot of strict control of costs and expenses
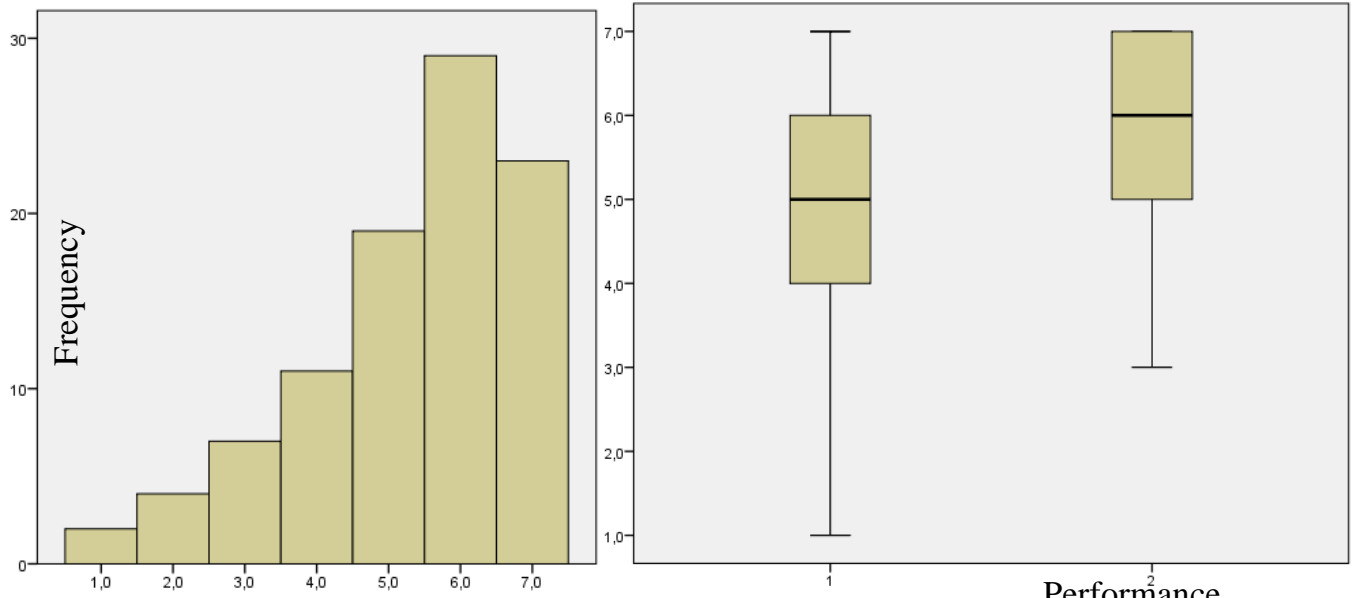

Source: Author (2020)

Performance

\subsubsection{Investment in $R \& D$, assistance, sales force and advertising}

As for investment in $R \& D$, sales force and advertising, the analysis is different from the previous ones. Graph 6 identifies that the histogram curve slopes to the left, that is, a large asymmetry of the curve, indicating low investment in these areas by most of the study participants. In the boxsplot, the median response of companies with low to medium performance is 1 and the median response of companies with medium to high performance is 3. This represents a difference in performance, however, both groups are not in the habit of investing in these areas, except for outliers (observations 02, 42 and 87). Outliers were companies considered atypical, that is, different from most respondents. As they represent only three companies out of 95 , these data did not interfere in the analyzes and conclusions.

Graph 6 - Histogram and boxsplot of investment in R\&D, assistance, sales force and advertising
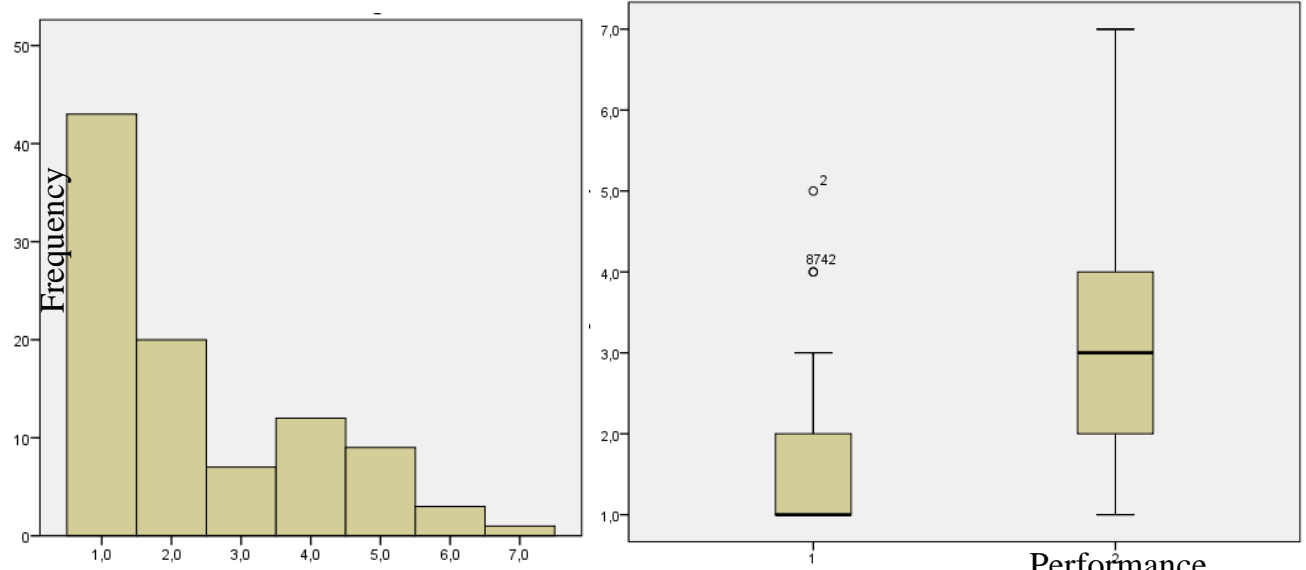

Source: Author (2020).

Performance 


\subsubsection{Lower cost compared to competitors}

Graph 7 illustrates whether there is a lower cost for products or services of the companies analyzed in relation to their competitors. The distribution is close to normal with concentration of responses at the center of the curve and, through the boxsplot. It is also observed that most companies chose an intermediate response independent of performance, with a median of 4 for both groups.

It appears that there are some outliers with better performance and higher cost than the competitors $(41,52,71$ and 82$)$, which theoretically would mean a willingness for a differentiation strategy, however, these same companies answered the positioning questions in different ways. In the case of better performance with lower cost (outliers 17, 63, 80 and 84), tending towards a cost strategy, it appears that three of the four companies responded using a cost strategy. The presence of outliers and concentration of responses around the mean, implies a lack of trend regarding the behavior of this variable in the sector.

Graph 7 - Histogram and boxsplot with lower cost compared to competitors
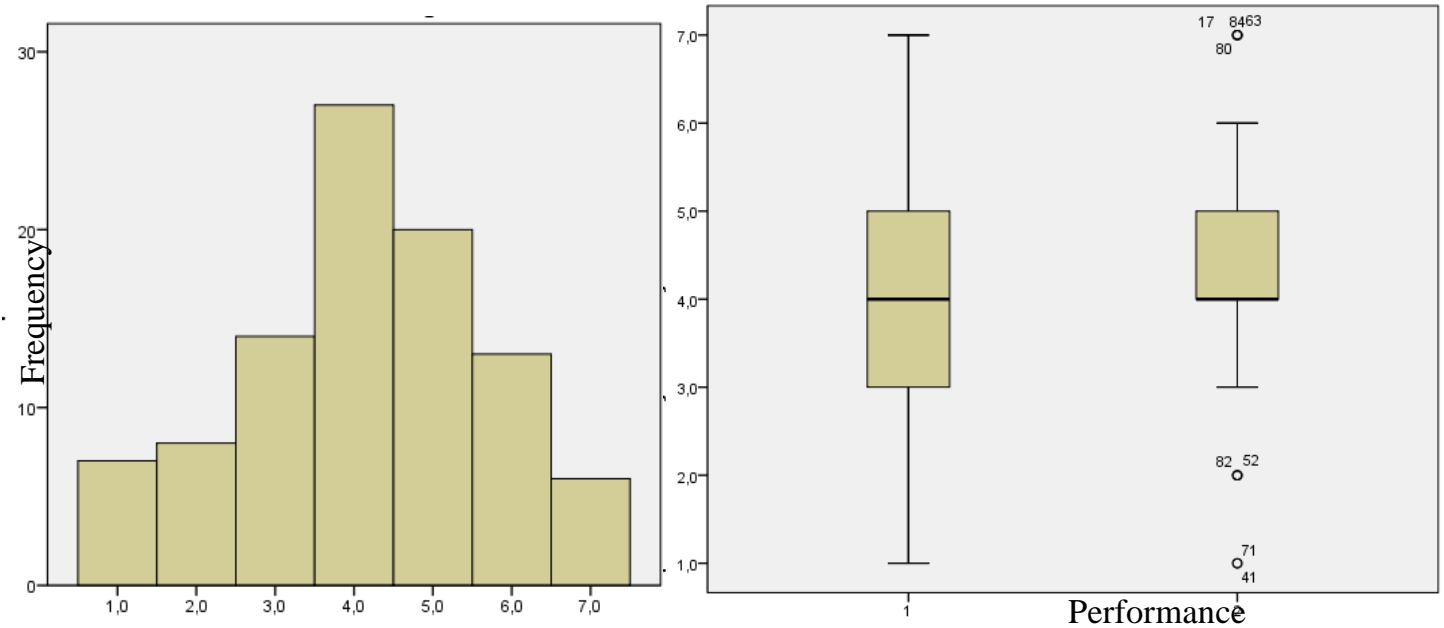

Source: Author (2020).

\subsubsection{Differentiated access to raw materials}

It is noted that having differentiated access to raw materials (Graph 8) compared to its competitors is not a consolidated feature in the analyzed group, since the histogram does not have a defined shape with a large dispersion of responses. The median of the boxsplot pointed to intermediate responses. 
Graph 8 - Differentiated access histogram and boxsplot with respect to raw materials
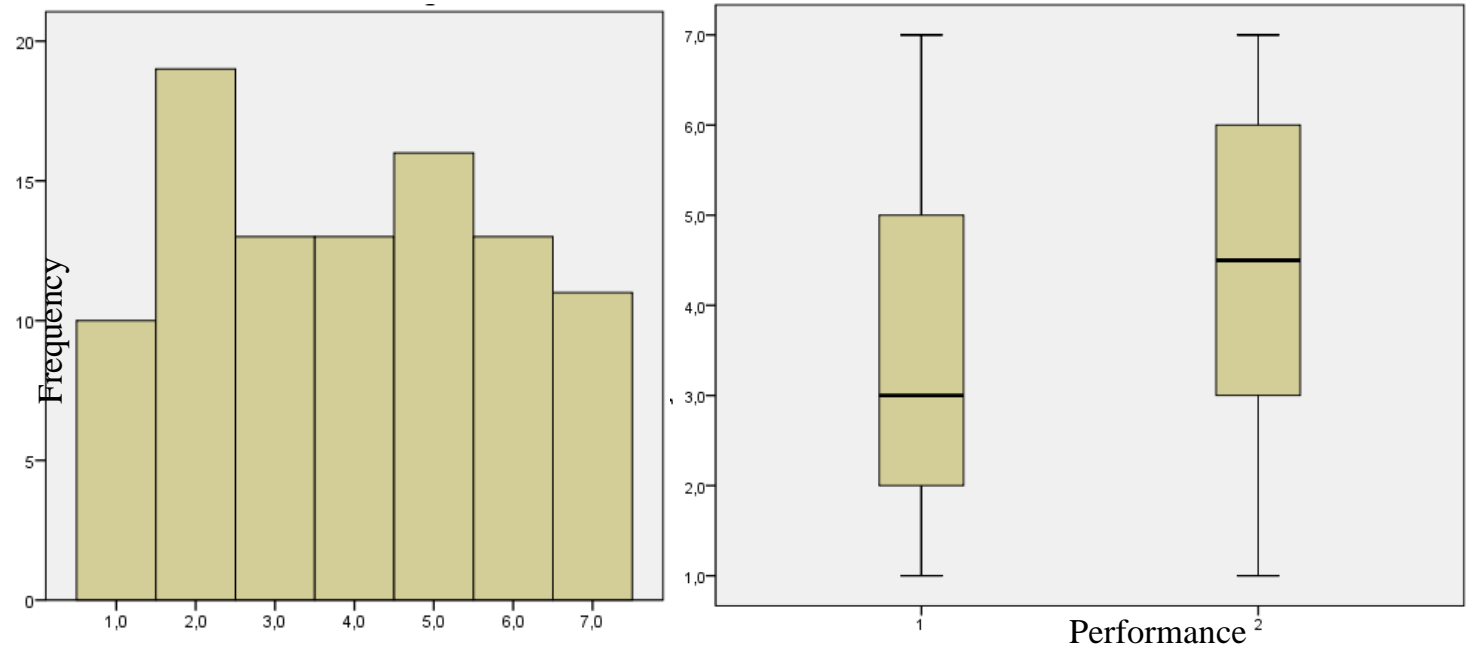

Source: Author (2020)

\subsubsection{Standardization of products / services}

Distinctively from the previous result, in the case of standardization of products or services with the objective of facilitating the operation, the Graph 9 shows that there is a certain inclination towards standardization, obtained mainly by the responses of the best performing organizations. A significant distance is perceived between the normal curves of the groups by the boxsplot in which the median of the group with the lowest performance is 3 and the best performance is 5 .

Graph 8 - Histogram and boxsplot of standardization of products / services
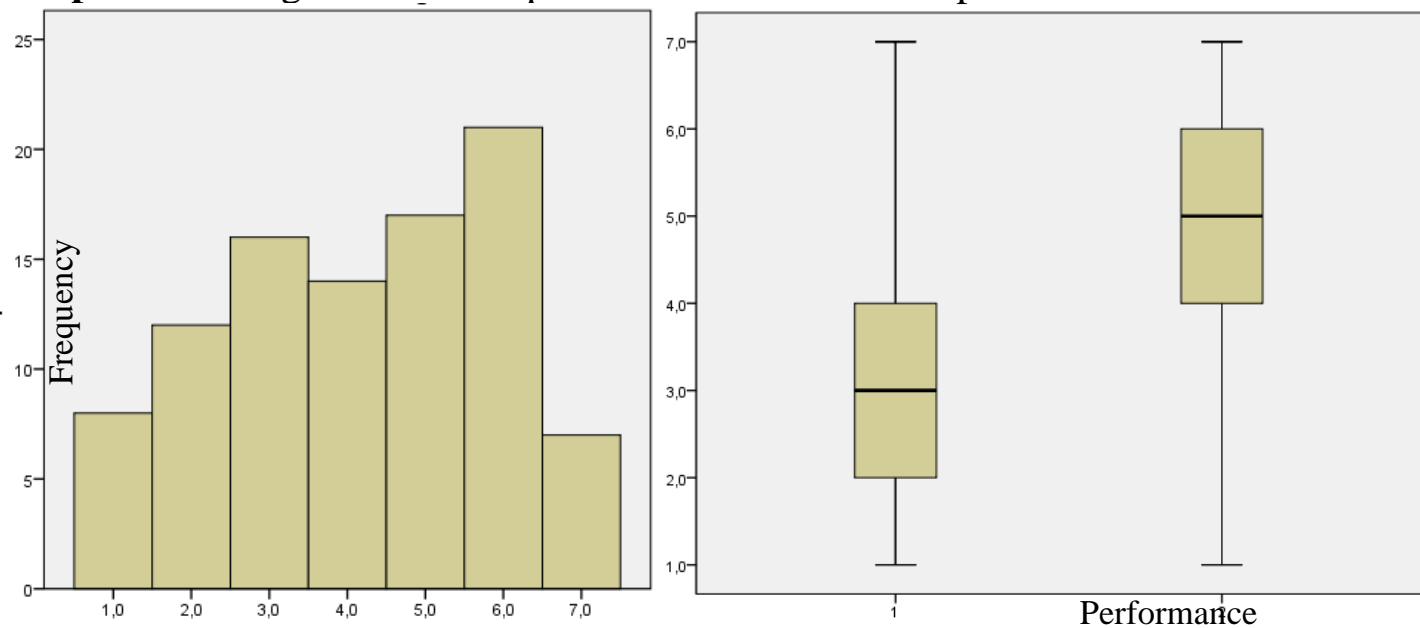

Source: Author (2020).

\subsubsection{Frequent and detailed control reports}

Using the histogram in Graph 10, it is not possible to ascertain the trend in the curve in relation to the use of frequent and detailed control reports. The answers are the most diverse. 
However, through the boxsplot, it is evident that companies with better performances usually have these reports, with a median of 5 , while companies with lower performance have a median of response 2 .

Graph 9 - Histogram and boxsplot of frequent and detailed control reports
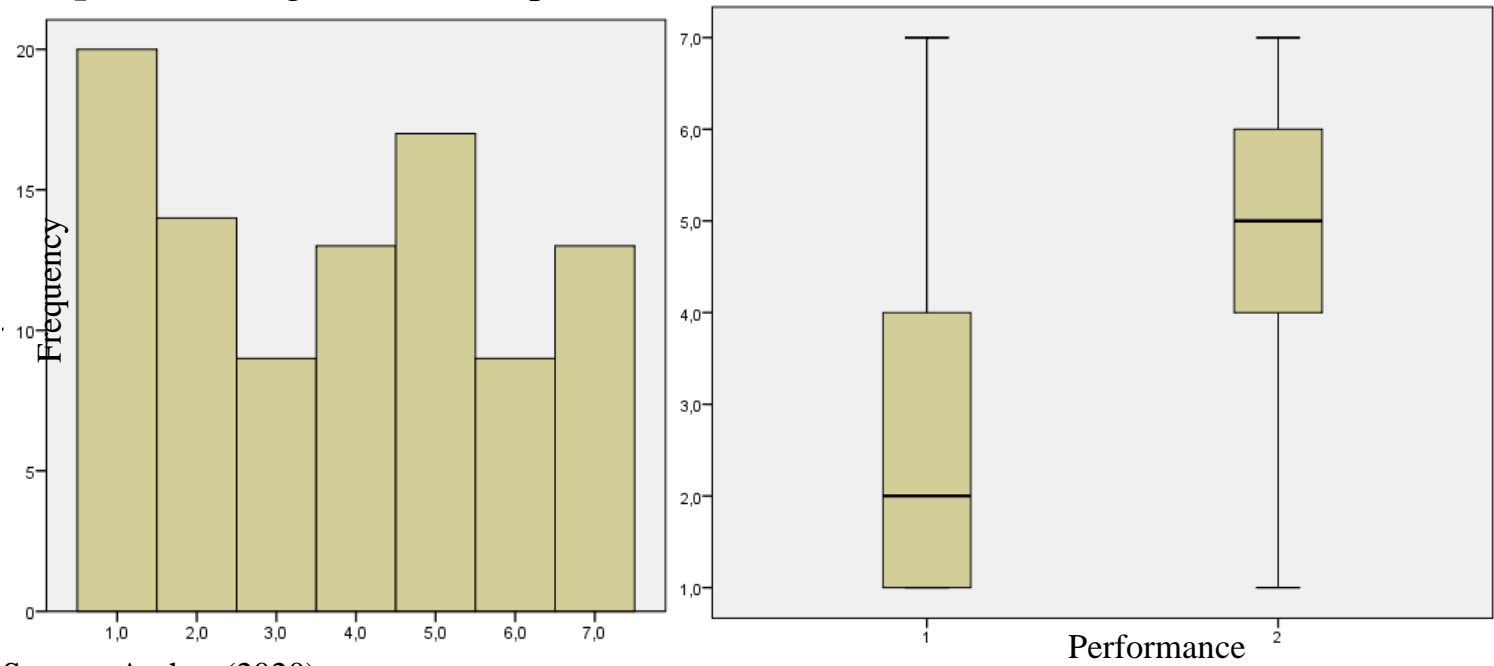

Source: Author (2020).

\subsubsection{Organization of management, structured roles and responsibilities}

The normal curve of the structuring of management, functions and responsibilities has a slight slope to the right, that is, proximity to high structuring (Graph 11). This result is driven by companies with superior performance, which, despite the dispersion of responses, has a median of 6 (closer to high structuring). However, it is not a consolidated policy for any group.

Graph 10 - Management organization histogram and boxsplot, structured roles and responsibilities
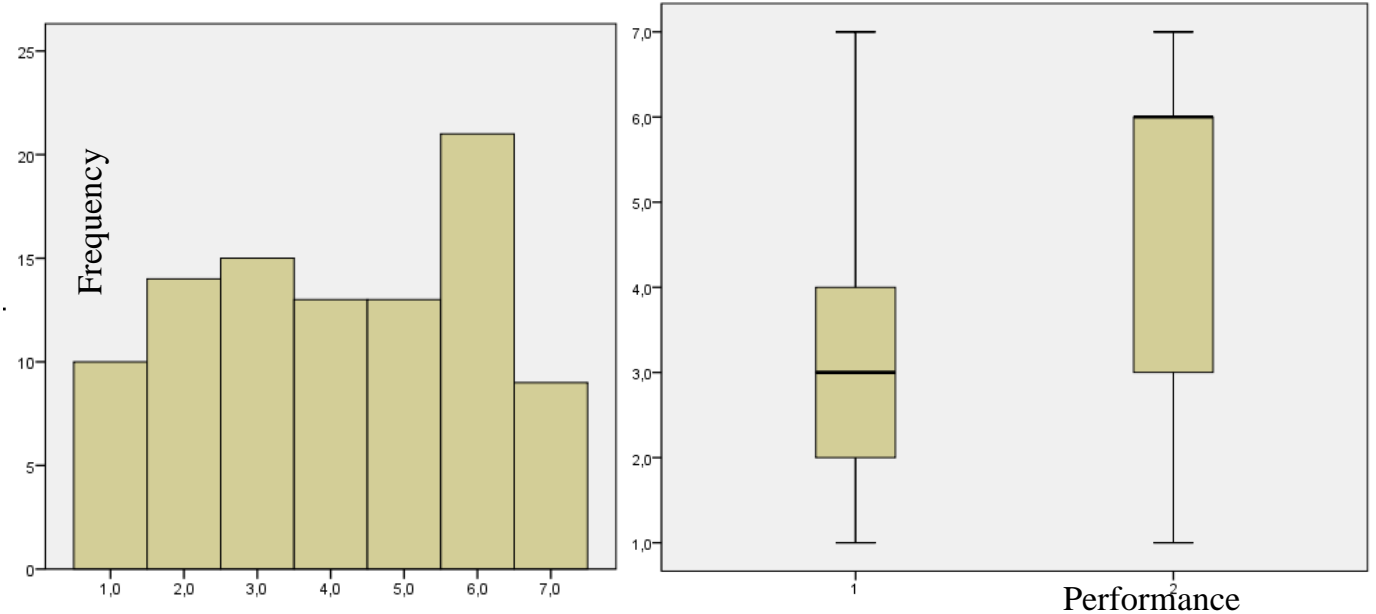

Source: Author (2020) 


\subsubsection{Continuous capital investments}

Continuous capital investments are shown in Graph 12. Little is deduced from the histogram curve on continuous investments due to the dispersion in the distribution of responses in the bar graph and little differentiation of responses for companies with different performances, as verified by the boxsplot.

Graph 11 - Continuous capital investment histogram and boxplot
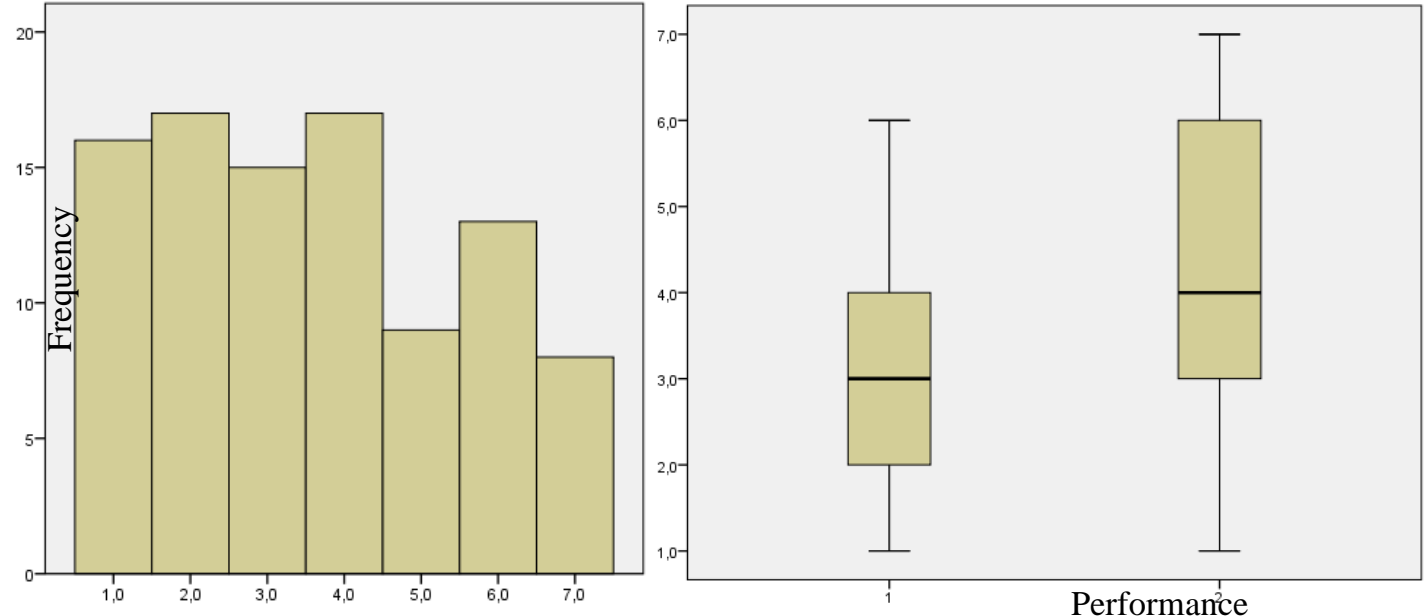

Source: Author (2020)

\subsubsection{Access to equity or third parties}

Graph 13 illustrates a trend towards easy access to equity or to third parties, according to the histogram analysis, seen by the slope of the curve on the right. Boxsplot shows little differentiation between organizations of different performances with close curves.

Graph 12 - Histogram and boxsplot for access to equity or third parties
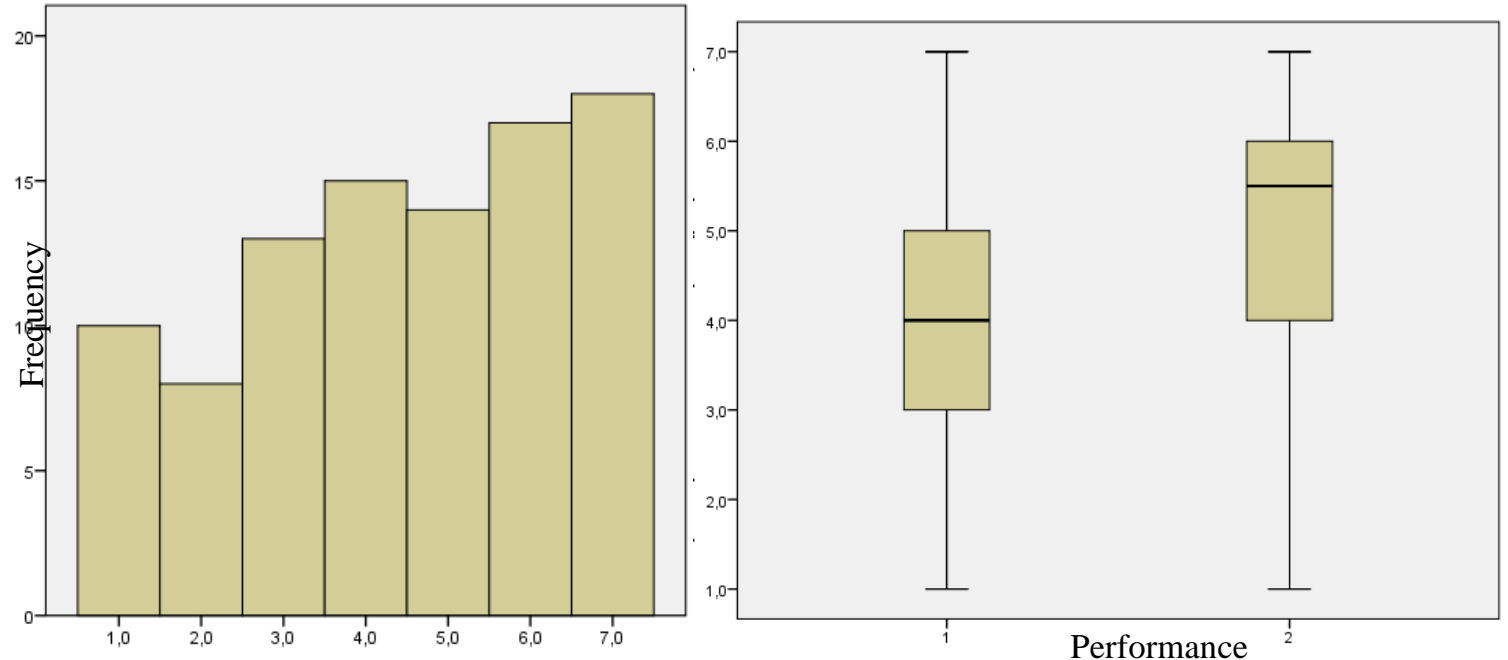

Source: Author (2020) 


\subsubsection{Process engineering skill}

Regarding the process engineering skill, the bar graph (Graph 14) is close to the normal curve, with greater volume in intermediate responses.

Graph 13 - Process engineering skill histogram and boxsplot
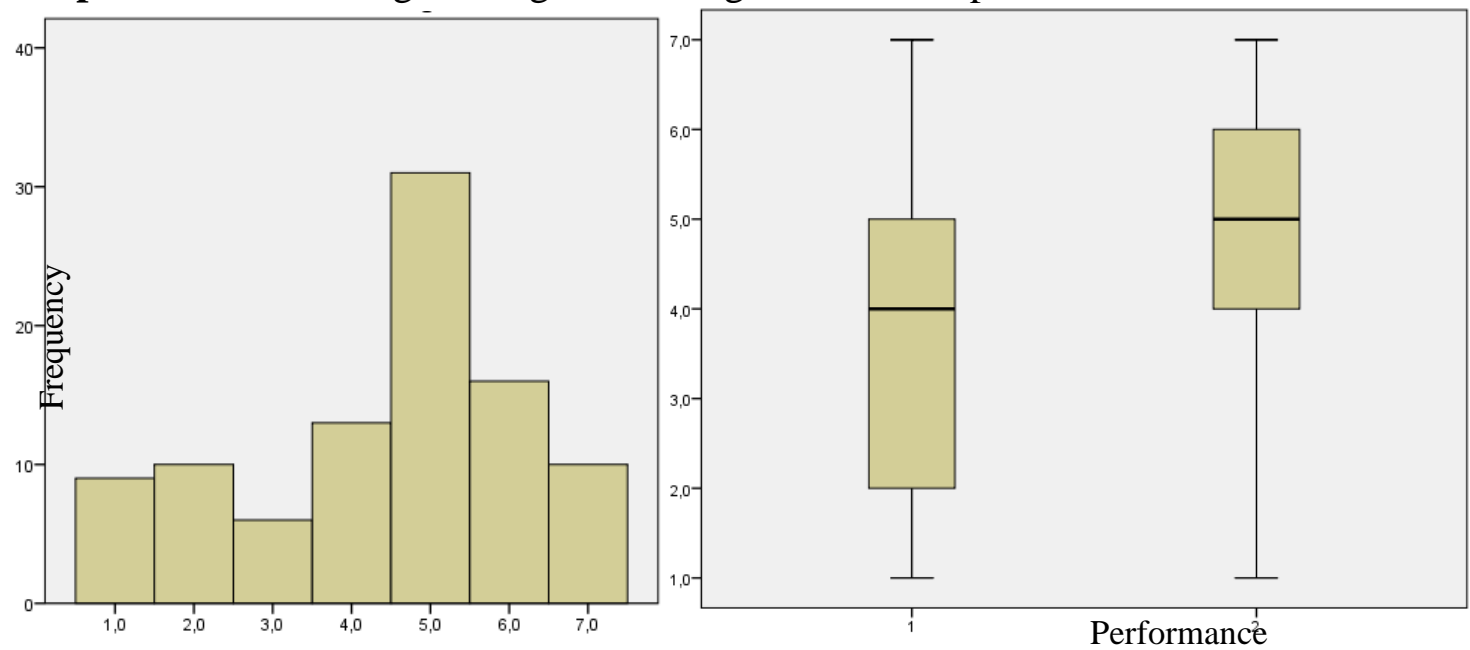

Source: Author (2020)

In boxsplot, low / medium performance companies have a median of 4 (intermediate response between extremes), while medium / high performance companies have a median of 5 , that is, a greater inclination to define this information, but little difference. This means that the result obtained on the bar graph revolves around more intermediate responses for process ability.

\subsubsection{Intense supervision of the workforce}

Graph 15 shows the level of labor supervision. There is a strong trend towards intense labor supervision both for companies with low / medium performance and for medium / high performance companies, as verified by the histogram.

In the boxsplot, the median of the companies with the lowest performance is 5 , while the companies with the highest performance have a median of 6 , that is, both have an intense supervision of the workforce, except for observations 10 and 51 of the sample. Outliers represent companies that, despite not having intense supervision of the labor force, present superior performance. As they represent only two companies out of 95, these data did not interfere in the analyzes and conclusions. 
Graph 14 - Histogram and boxsplot of intense supervision of the workforce
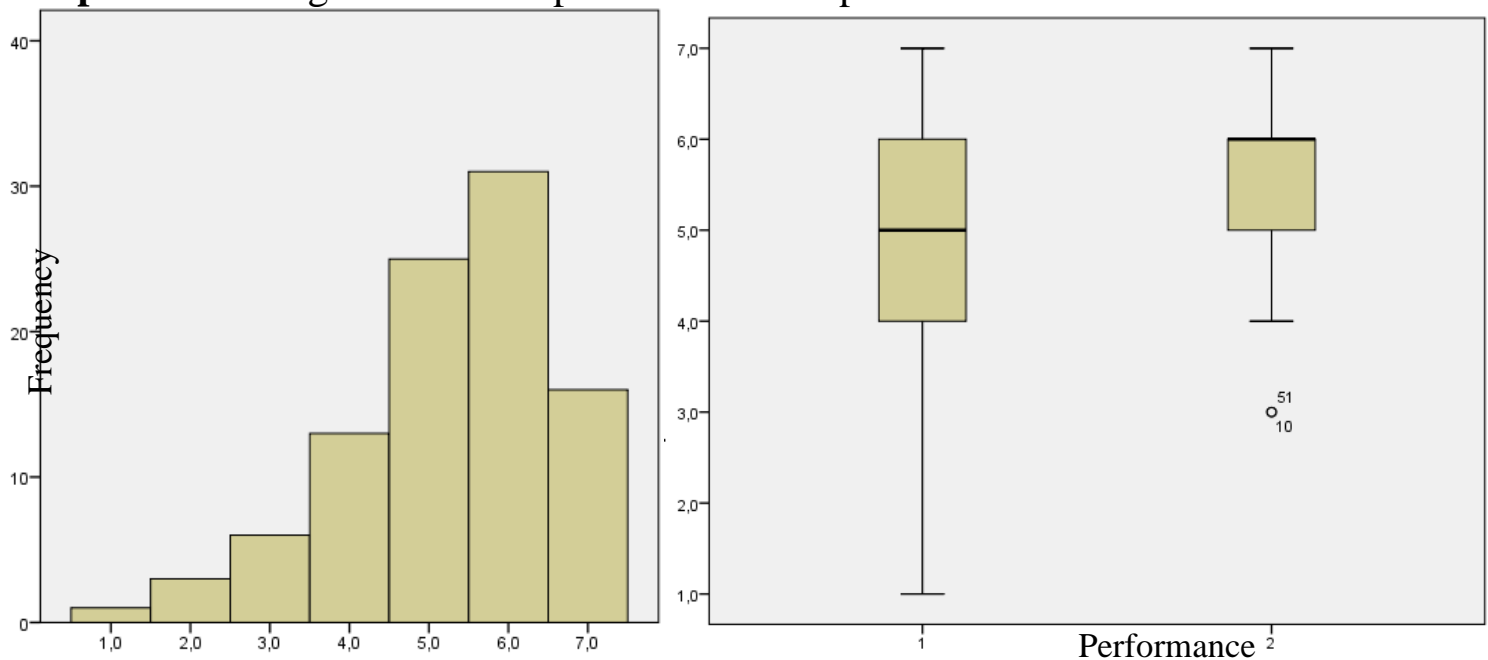

Source: Author (2020)

\subsubsection{Aggressively launching products / services}

The analysis of launching product or service aggressively on an efficient scale shows the tendency for a few aggressively launches by the histogram inclination to the left (Graph 16).

Underperforming companies are clearly less aggressive, except for four outliers who launch products and services more aggressively and performance is low to average. Because the outliers represent only four companies out of 95, these data did not interfere with the analysis and conclusions of this variable. In organizations with superior performance there is a great dispersion of response with the median being an intermediate result (neither too aggressive nor too aggressive).

Graph 15 - Histogram and boxsplot to launch products / services aggressively

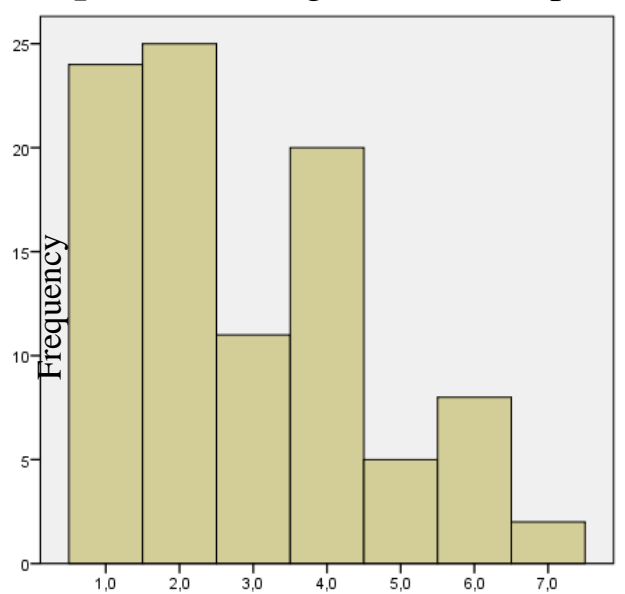

Source: Author (2020).

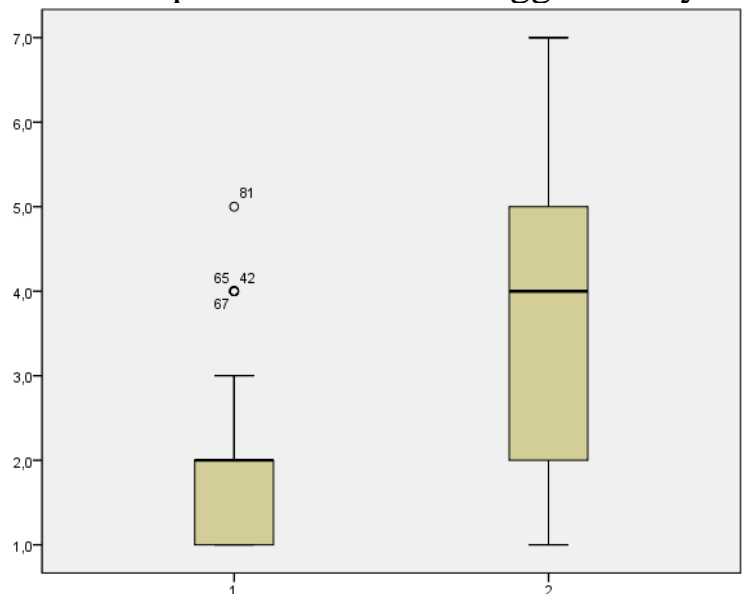

Performance 


\subsubsection{Reward for quantitative goals}

The bar graph (Graph 17) shows rewards for quantitative goals for entrepreneurial initiatives and attitudes.

Graph 17 - Histogram and reward boxsplot for quantitative goals
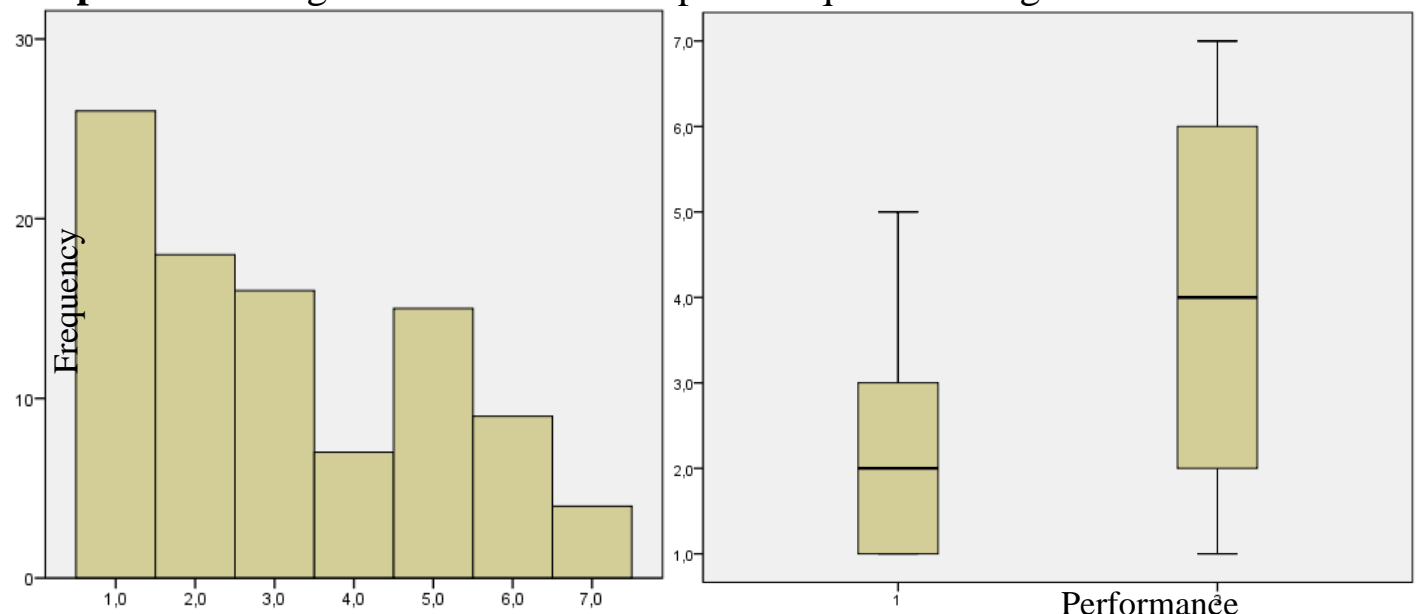

Source: Author (2020).

Most companies do not have quantitative targets, visually verified in the asymmetry of the curve on the left. For organizations with higher performance, the dispersion is large around the median, with median response 4, but organizations with inferior performance have few or no rewards, with median response 2 in the boxsplot. It is concluded that the use of quantitative targets is not a consolidated policy in the field of civil construction.

\subsubsection{Cost concern over competitors}

Graph 18 shows that there is a strong tendency to worry about cost in relation to competitors, both for companies with better or worse performance, illustrated by the asymmetry of the curve on the right. In boxsplot, both performance groups have a high median, reinforcing the idea that most of the respondent establishments have this concern. 
Graph 16 - Histogram and boxsplot of cost concern in relation to competitors
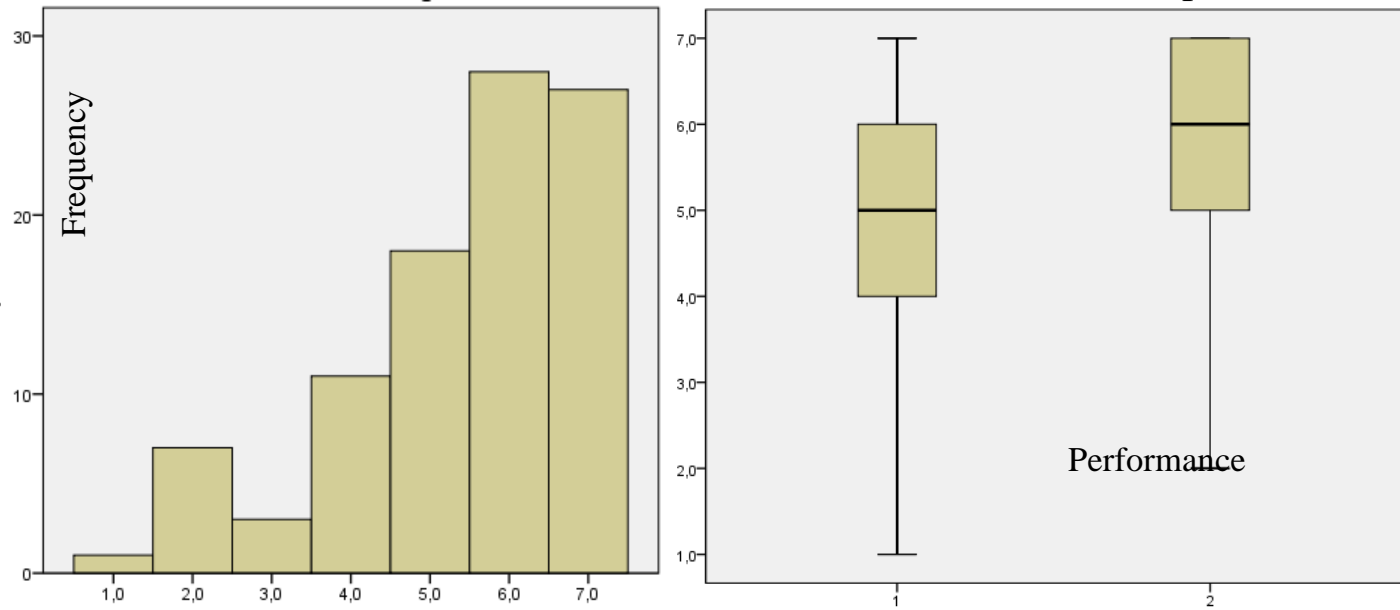

Source: Author (2020)

Of the fifteen cost strategy policies, it appears that four are followed by most companies, which would be: the vigorous pursuit of cost reductions as the company acquires market experience, the strict control of costs and expenses, the intense supervision of labor and concern with the cost of its products / services in relation to its competitors. The other policies did not stand out in the responses. There is a certain standardization of products / services, organization of management, structured functions and responsibilities, easy access to third party or own capital, frequent and detailed control reports for companies with superior performance. There is also a low investment in $\mathrm{R} \& \mathrm{D}$, assistance, sales force and advertising without launching products / services on an aggressive scale as well. The volume of cost policies used is consistent with the results in section 4.1.1, in which $18 \%$ of companies are classified with their positioning entirely in cost.

\subsubsection{Dependent variables}

For the dependent variables, seven questions have been asked (Table 8).

Table 8 - Dependent variables

Financial result

\begin{tabular}{l|l|l|l|l|l|l|l|l|l|l}
\hline 38 & $\begin{array}{l}\text { The average profitability of the business over the past } \\
\text { two years: }\end{array}$ & None & $\mathbf{1}$ & $\mathbf{2}$ & $\mathbf{3}$ & $\mathbf{4}$ & $\mathbf{5}$ & $\mathbf{6}$ & $\mathbf{7}$ & $\begin{array}{l}\text { Extremely } \\
\text { high }(> \\
20 \%)\end{array}$ \\
\hline 39 & The company's growth rate over the past two years: & Zero & $\mathbf{1}$ & $\mathbf{2}$ & $\mathbf{3}$ & $\mathbf{4}$ & $\mathbf{5}$ & $\mathbf{6}$ & $\begin{array}{l}\mathbf{7} \\
\text { Exigh }(> \\
20 \%)\end{array}$ \\
\hline
\end{tabular}

Human Resources

\begin{tabular}{l|l|l|l|l|l|l|l|l|l|l}
\hline 37 & What is the level of employee turnover? & High & $\mathbf{1}$ & $\mathbf{2}$ & $\mathbf{3}$ & $\mathbf{4}$ & $\mathbf{5}$ & $\mathbf{6}$ & $\mathbf{7}$ & Low \\
\hline 32 & $\begin{array}{l}\text { Do employees work as a team in pursuit of the } \\
\text { strategy's realization? }\end{array}$ & $\begin{array}{l}\text { Work } \\
\text { individually }\end{array}$ & $\mathbf{1}$ & $\mathbf{2}$ & $\mathbf{3}$ & $\mathbf{4}$ & $\mathbf{5}$ & $\mathbf{6}$ & $\mathbf{7}$ & $\begin{array}{l}\text { Work as a } \\
\text { team }\end{array}$ \\
\hline
\end{tabular}




\begin{tabular}{l|l|l|l|l|l|l|l|l|l|l} 
& implemented & & & & & & & implemented \\
\hline 34 & $\begin{array}{l}\text { How present are the strategic orientations in the day-to- } \\
\text { day decisions? }\end{array}$ & $\begin{array}{l}\text { Little or } \\
\text { nothing present }\end{array}$ & $\mathbf{1}$ & $\mathbf{2}$ & $\mathbf{3}$ & $\mathbf{4}$ & $\mathbf{5}$ & $\mathbf{6}$ & $\mathbf{7}$ & $\begin{array}{l}\text { Extremely } \\
\text { present }\end{array}$ \\
\hline
\end{tabular}
Flexibility

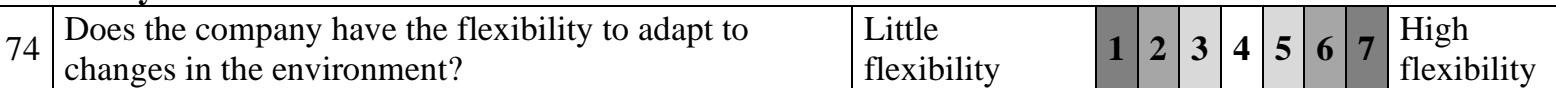
Source: Author (2020).

As for the dependent variables of the study, the average business profitability in the last two years presents a great diversity of responses by the respondents, with the majority focusing on an intermediate profitability. The establishments growth rate of the last two years shows a tendency for a low or no growth, consistent with the market situation presented in the civil construction scenario. The level of employee turnover is low and the same result is found in the study by Arif, Azhar and Bayraktar (2012).

There is a tendency for employees to work as a team in pursuit of the strategy, as also identified in El-Hallaq and Tayeh (2015). The effectiveness of the implementation of strategies and the presence of strategic guidelines in day-to-day decisions have a great diversity of responses, however the greatest concentration is around the average, that is, indicating the partial implementation of the strategies. In El-Hallaq and Tayeh (2015), companies apply most of the strategies. Mahmood et al. (2017), and Oyewobi, Windapo and Rotimi (2017) conclude that there is evidence that corporate values and strategy are important internal factors in determining a company's performance in addition to other organizational factors.

Strategic orientations are neither too little nor too present in day-to-day decisions. As for the versatility to adapt to changes that occur in the environment, there is a tendency to high flexibility to meet new demands, according to the respondents, consistent with ElHallaq and Tayeh (2015) and Maia (2014). In Bhattacharya, Momaya and Iyer (2013) there is a reluctance in new knowledge and solutions presenting difficulty in changes.

\subsection{Discriminant Analysis}

Multiple discriminant analysis is a dependency technique that distinguishes groups based on the set of variables (HAIR JR et al., 2005b, p. 27). The analysis purpose is to discover the differences of the analyzed groups by predicting the possibility of an individual or object belonging to a group considering the independent variables. In addition, it is possible to determine whether there are significant differences between the groups and to classify new individuals in the groups based on the obtained discriminant functions 
(FIPECAFI, 2007, p. 6). The two main assumptions of the discriminant analysis are the existence of multivariate normality and homogeneity of the variance and covariance matrices for the groups (HAIR JR et al., 2005b). For the study of multivariate analysis, the prerequisites for normality of the variables of the cost characteristics were verified using the histogram and the minimum amount of data to perform the analyzes. Based on this, questions have been removed from the analysis, which had a histogram quite different from the normal one, according to the prerequisites of the multivariate analysis, and with a p-value above 0.05 in the group average equality tests. The other variables have been considered in the study.

The construct "Characteristics of cost strategy", with 4 variables, two groups (low / medium performance and medium / high performance) and 95 observations, meets the minimum of 5 observations per variable and the smallest group (45 observations for low / medium performance), is greater than the number of independent variables exceeding the required minimum of 20 observations for each analyzed group (HAIR JR et al., 2005b, p. 220). The test for equality of variables is shown in Table 9.

Table 9 - Group average equality tests for "Cost Strategy Features"

\section{Group average equality tests}

\begin{tabular}{|c|c|c|c|c|}
\hline $\mathrm{N}$ & Questions & $\begin{array}{l}\text { Wilks } \\
\text { Lambda }\end{array}$ & $\mathrm{F}$ & g12 Sig. \\
\hline 46 & $\begin{array}{l}\text { Is there a certain simplification / standardization of products } \\
\text { / services to facilitate operation? }\end{array}$ & 0,766 & 28,3861 & 930,000 \\
\hline 48 & $\begin{array}{l}\text { Does the company have a structured management } \\
\text { organization, functions and responsibilities? }\end{array}$ & 0,787 & 25,1101 & 930,000 \\
\hline 51 & Does the company use process engineering skills? & 0,937 & 6,2281 & 930,014 \\
\hline$\overline{52}$ & Is there intense supervision of the workforce? & 0,845 & 17,0221 & 930,000 \\
\hline
\end{tabular}
Source: Author (2020).

The Box M indicates that there is equality in the covariance matrix (Table 10) meeting one of the assumptions of the discriminant analysis.

Table 10 - Box M for "Characteristics of the cost strategy"

\begin{tabular}{lll}
\hline \multicolumn{2}{l}{ Tests Results } \\
\hline Box M & & 14,157 \\
\hline F & Approx. & 1,350 \\
\cline { 2 - 3 } & gl1 & 10 \\
\hline gl2 & 40291,741 \\
\hline & Sig. & 0,197 \\
\hline
\end{tabular}

Source: Author (2020).

Tests null hypothesis of covariance matrices of equal population. 
The eigenvalue in Table 11 confirms the existence of a discriminating function that explains the variance between the groups of variables analyzed having high significance (Table 12).

Table 11 - Eigenvalues for "Characteristics of the cost strategy"

\begin{tabular}{|c|c|c|c|c|}
\hline \multicolumn{5}{|c|}{ Eigenvalues } \\
\hline Function & Eigenvalues & $\%$ of variance & $\%$ cumulative & Canonical correlation \\
\hline 1 & $0,548^{\mathrm{a}}$ & 100,0 & 100,0 & 0,595 \\
\hline
\end{tabular}

Source: Author (2020).

Table 12 - Wilks' Lambda for "Cost Strategy Characteristics" Lambda de Wilks

\begin{tabular}{lllll}
\hline Function testing & Wilks Lambda & Chi-square & gl & Sig. \\
\hline 1 & 0,646 & 39,784 & 4 & 0,000 \\
\hline
\end{tabular}

Source: Author (2020).

The standardized canonical discriminating function coefficients present as the most discriminating variable "the company has a structured management organization, functions and responsibilities" (Table 13). Remarkably close to this variable in importance is the variable that indicates a certain standardization / simplification of products / services to facilitate the operation.

Table 13 - Standardized canonical discriminating function coefficients for "Cost strategy characteristics"

Standardized canonical discriminating function coefficients

\begin{tabular}{ll}
\hline & Function \\
\hline Is there a certain simplification / standardization of products / services to facilitate operation? & 1 \\
\hline Does the company have a structured management organization, functions and responsibilities? & 0,550 \\
\hline Does the company use process engineering skills? & 0,555 \\
\hline Is there intense supervision of the workforce? & $-0,081$ \\
\hline
\end{tabular}

Source: Author (2020).

In the structure matrix, the discriminating variable is the standardization /

simplification of products / services (Table 14).

Table 14 - Structure matrix for "Cost strategy characteristics"

\begin{tabular}{ll}
\hline Structure matrix & $\frac{\text { Function }}{1}$ \\
\hline Is there a certain simplification / standardization of products / services to facilitate operation? & 0,746 \\
\hline Does the company have a structured management organization, functions and responsibilities? & 0,702 \\
\hline Is there intense supervision of the workforce? & 0,578 \\
\hline Does the company use process engineering skills? & 0,349 \\
\hline Correlations between groups in the set between discriminating variables and standardized canonical \\
discriminating functions
\end{tabular}


The discriminating power by the number of correct classifications have reached above the minimum for the Q de Press, with 74 correct observations and $77.9 \%$ of the grouped cases correctly classified (Table 15).

$$
Q \text { de Press }=\frac{[N-(n K)]^{2}}{N(K-1)}=\frac{[95-(74 \times 2)]^{2}}{95(2-1)}=29,57
$$

Table 15 - Classification results for "Characteristics of the cost strategy"

\begin{tabular}{|c|c|c|c|c|c|}
\hline \multicolumn{6}{|c|}{ Classification results $^{\mathrm{a}}$} \\
\hline & & \multirow[t]{2}{*}{ Performance Rating } & \multicolumn{2}{|l|}{ Group } & \\
\hline & & & 1 & 2 & Total \\
\hline \multirow[t]{4}{*}{ Original } & Score & 1 & 33 & 12 & 45 \\
\hline & & 2 & 9 & 41 & 50 \\
\hline & $\%$ & 1 & 73,3 & 26,7 & 100,0 \\
\hline & & 2 & 18,0 & 82,0 & 100,0 \\
\hline
\end{tabular}

a. $77,9 \%$ of correctly grouped original grouped cases

Source: Author (2020).

Analyzing this result with the visual analysis of the boxsplots presented in section 4.1.2, it appears that the product and service simplification variable is the question that presents the greatest distance between the normal curves of the groups. In this way, the companies that use the policy of greater simplification / standardization of products / services are the organizations are more likely to obtain a superior performance when compared to the companies with lower performance.

\section{DISCUSSION}

The study results outline the profile of the companies analyzed. Most respondents work in the field of construction, renovation and / or residential maintenance. Considering the gross annual revenue, small companies are more representative in the study. They have, in large part, family management and lack of investment in quality certification.

The focus on some leadership strategy represents better results for companies, however the focus on niches did not present a significant difference in performance. Of the total companies interviewed, only $18 \%$ focus heavily on differentiation and $18 \%$ focus heavily on cost. Of the remaining, $25 \%$ have low use of both positioning strategies, $21 \%$ use both positioning strategies strongly, and $18 \%$ have intermediate responses. The data shows that only $36 \%$ of companies are positioned for only one of the strategies. Thus, the result 
implies that the rest of the companies do not have a unique strategic positioning, in line with studies by Maia (2014) and Chinowsky and Meredith (2000). According to Porter's theory (1986), the focus must be given either to cost leadership or to differentiation leadership.

Regarding cost strategy policies, the vigorous pursuit of cost reductions as the company gains market experience, strict control of costs and overheads, intense supervision of the workforce and concern for cost in relation to competitors are policies strongly followed by survey respondents, where there is little or no influence of performance on the result. Companies with better performances usually have frequent and detailed control reports, standardization or simplification of products or services and structuring of management, functions and responsibilities.

Investment in $\mathrm{R} \& \mathrm{D}$, sales force and advertising, and rewards for quantitative goals for entrepreneurial initiatives and attitudes are policies least followed by most companies, especially for underperforming organizations. In the study by Arif, Azhar and Bayraktar (2012), the 18 companies analyzed in the industry demonstrated that R\&D is the weakest link in the strategic management approach of the construction industry.

Respondents' average business profitability over the past two years shows a wide range of responses with the majority focusing on intermediate profitability. The growth rate of the last two years of the establishments participating in the survey shows a tendency for a low or no growth consistent with the market situation presented in the civil construction scenario.

The level of employee turnover is low, and the same result is found in the study by Arif, Azhar and Bayraktar (2012). There is a tendency for employees to work as a team in pursuit of the strategy, as also identified in El-Hallaq and Tayeh (2015). The effectiveness of the implementation of strategies and the presence of strategic guidelines in day-to-day decisions have a great diversity of responses, however the greatest concentration is around the average indicating the partial implementation of the strategies. In El-Hallaq and Tayeh (2015), companies apply most of the strategies. Mahmood et al. (2017), and Oyewobi, Windapo and Rotimi (2017) have concluded that there is evidence that corporate values and strategy are important internal factors in determining a company's performance, in addition to other organizational factors.

Strategic guidelines that are neither too little nor too present. As for the versatility to adapt to changes that occur in the environment, there is a tendency to high flexibility to meet new demands, according to the respondents, consistent with El-Hallaq and Tayeh (2015) and 
Maia (2014). In Bhattacharya, Momaya and Iyer (2013) there is a reluctance in new knowledge and solutions presenting difficulty in changes.

Through the discriminant analysis, it appears that the variable that most discriminated against the performance groups was the variable related to the simplification of products and services. That said, the companies that use the policy of greater simplification / standardization of products / services are the organizations that are most likely to obtain a higher performance when compared to the companies with lower performance.

\section{CONCLUSION}

This work evaluates the influence of cost strategy policies on the performance of micro, small and medium-sized companies in the civil construction sector, located in Curitiba and RMC, considering the volatile scenario of the economic environment, whose activities are construction, renovations and / or maintenance for residential, commercial, industrial and other non-residential uses; infrastructure works and specialized services.

This research has collected data from 95 companies through a structured questionnaire. The data collection phase started in March 2018 and ended in August 2018. In summary, the most evident profile identified in the study has been a small company with centralized family management with an inclination for individualized strategic decisions, in which the owner is an engineer. These organizations do not usually obtain quality certifications. Only $36 \%$ of the companies had a strategic position. However, some cost policies are followed strongly by most companies. The cost strategy variable that most influenced companies' performance was standardization / simplification of products / services to facilitate the operation. Few companies exhibited strategic positioning and there was a tie in the most used positioning strategy. It was possible to verify the lack of strategic thinking in the construction industry, emphasized by several authors.

Analyzing the research objective, the conclusion is that there is a positive influence of cost strategy policies on the performance of micro, small and medium-sized companies in the construction industry in Curitiba and the Metropolitan Region, considering the variables of the study. Top-performing organizations tend to implement most of Porter's strategic management practices. 
The conclusion is that the strategic management model brings important knowledge to the challenge of preserving itself in the market, where not only the technologies of execution and inputs are important, but also management mechanisms that allow to achieve superior gains. Consequently, the study encourages the development of the strategy theme in the civil construction sector in the search for better results.

An environment where resilience is a scarce commodity, a company that has the flexibility to adapt to the changes that occur in the environment and performs strategic management has remarkable chances of achieving competitive advantages in the sector. How long will companies in the construction industry continue to put strategic management aside? How long will companies remain managing their establishments the same way?

Throughout the study some limitations have been found. Data collection has been very exhaustive with lower return than expected. Many companies did not want to participate for fear that individual management information would be released.

It is important to emphasize that there is subjectivity in the questionnaire that can affect interpretations. As it is a descriptive study, based on a non-probabilistic sample, the generalization of the results achieved must be carefully analyzed. Considering the relevance of the topic and the construction industry, the article is important and needs further studies.

As a recommendation for future work, it is possible to use the same study methodology, expanding the information collected, as well as expanding the sample. The reverse is also feasible: reducing the number of variables to further expand the sampling by reducing the response time. Another suggestion would be a comparison with the results obtained in this study and the results in later years to verify the improvements obtained in the period. And finally, there is the possibility to make comparisons with other markets and check patterns.

\section{References}

ALMEIDA, D. C. de; MARTINS, J. E. B.; CAMPOS, I. B.; BARROS-NETO, J. P. Análise bibliométrica sobre a produção científica Brasileira em estratégia na construção civil no Período de 2000 a 2011. In: ENCONTRO NACIONAL DE TECNOLOGIA DO AMBIENTE CONSTRUÍDO, n.14. 2012. Anais... ENTAC, Juiz de Fora, MG, 2012.

ARIF, F.; AZHAR, N.; BAYRAKTAR, M. E. Strategic Management Concepts and Practices in Pakistan: A Construction Industry Perspective. In: CONSTRUCTION RESEARCH 
CONGRESS, Anais... ASCE, 2012.

BHATTACHARYA, S.; MOMAYA, K. S.; IYER, C. Latent factors among enablers of growth: a study in the context of construction companies in India. Journal of Advances in Management Research, v. 10, n. 1, p. 45-57, 2013.

BANCO NACIONAL DO DESENVOLVIMENTO (BNDES). Classificação do porte dos clientes. Available in: <https://www.bndes.gov.br/wps/portal/site/home/financia mento/guia/quem-pode-ser-cliente/>. Accessed on: August 2017.

CÂMARA BRASILEIRA DA INDÚSTRIA DA CONSTRUÇÃO (CBIC). PIB 2015. Available in: <http://www.cbicdados.com.br/menu/home/pib-2015>. March, 2016b. Accessed on: August 18, 2016.

CHINOWSKY, P. S; MEREDITH, J. E. Strategic Management in Construction. Journal of Construction Engineering and Management, v.126, n.1, p. 1-9, 2000.

COSTA, G. S.; VIEIRA, J. P. P.; BARROS-NETO, J. P. Análise da produção científica em estratégia com foco na construção civil: ENTAC e SIBRAGEC de 2000 a 2009. In: ENCONTRO NACIONAL DE TECNOLOGIA DO AMBIENTE CONSTRUÍDO, Anais...ENTAC, Canela, RS, 2010.

EL-HALLAQ, K.; TAYEH, B. A. Strategic Planning in Construction Companies Gaza Strip. Journal of Engineering Research and Technology, v.2, n.2, 2015.

FERREIRA, A. B. H. Novo dicionário Aurélio da língua portuguesa. 4. ed. Curitiba: Ed Positivo, 2009.

FIPECAFI (Fundação Instituto de Pesquisas Contáveis, Atuariais e Financeiras). Análise multivariada: para os cursos de administração, ciências contábeis e economia. São Paulo: Atlas, 2007.

GIL, A. C. Como elaborar projetos de pesquisa. 5. ed. São Paulo: Atlas, 2010.

GRANT, R. M. Toward a knowledge-based theory of the firm. Strategic Management Journal, v.17, n.1, p. 109-122, 1996.

HAIR JR, J. F.; BLACK, W. C.; BABIN, B. J.; ANDERSON, R. E.; TATHAM, R. L. Análise multivariada dos dados. Translation Adonai Schlup Sant'Anna. 6. ed. Porto Alegre: Bookman, 2009.

HAIR JR, J. F.; BABIN, B.; MONEY, A. H.; SAMOUEL, P. Fundamentos de métodos de pesquisa em administração. Porto Alegre: Bookman, 2005a.

HAIR JR, J. F.; BLACK, W. C.; BABIN, B. J.; ANDERSON, R. E.; TATHAM, R. L. Análise multivariada dos dados. Translation Adonai Schlup Sant'Anna. 5. ed. Porto Alegre: Bookman, 2005b.

HO, P. H. K. Analysis of Competitive Environments, Business Strategies, and Performance in 
Hong Kong's Construction Industry. Journal of Management in Engineering, v. 32, n. 2, 2016.

INSTITUTO BRASILEIRO DE GEOGRAFIA E ESTATÍSTICA (IBGE). Classificação Nacional de Atividades Econômicas (CNAE). Versão 2.0. Rio de Janeiro, 2007. Available on: < https://cnae.ibge.gov.br/documentacao/ documentacao-cnae-2-0.html>. Accessed on: August 20, 2018.

Série histórica Contas Nacionais trimestrais. Pesquisa Anual da Construção Civil. v. 26. Rio de Janeiro, 2016.

INSTITUTO BRASILEIRO DE ECONOMIA (IBRE). Boletim Macro. Retomada em meio à incerteza. June, 2020.

. Economia em compasso de espera em um contexto de acirramento da guerra comercial e de intensa polarização eleitoral. September, 2018a.

Sondagem da construção. September, 2018b.

KAPLAN, R. S.; NORTON, D. P. A Estratégia em ação: Balanced scorecard. Rio de Janeiro: Campus, 1997.

KÖCHE, J. C. Fundamentos de metodologia científica: teoria da ciência e iniciação à pesquisa. 34. ed. Petrópolis, RJ: Vozes, 2015.

LAKATOS, E. M.; MARCONI, M. A. Fundamentos de metodologia científica. 8. ed. São Paulo: Atlas, 2017.

MACIEL, F. W. F.; CÂNDIDO, L. F. Proposta de um sistema de indicadores de desempenho para empreendimentos de construção. In: SIMPÓSIO DE ENGENHARIA DE PRODUÇÃO, n. 23, 2016. Anais...SIMPEP, Bauru, São Paulo, 2016.

MAHMOOD, R.; ZAHARI, A. S. M.; YAACOB, N. M.; ZIN, S. M. Small firm performance: an empirical analysis in Malaysian housing construction industry. International Journal of Housing Markets and Analysis, v.10, n. 1, p. 50-65, 2017.

MAIA, A. T. Análise setorial das características organizacionais e do nível de efetividade dos processos gerenciais de empresas de construção civil. 2014. 267 f. Dissertação (Mestrado) - Programa de Pós-graduação em Engenharia Civil, Universidade Tecnológica Federal do Paraná. Curitiba, 2014.

MINTZBERG, H. Ascensão e queda do planejamento estratégico. Porto Alegre: Bookman, 2004.

OYEWOBI, L. O.; WINDAPO, A. O.; ROTIMI, J. O. B. Determinants of construction organisational performance: A partial least square-path analytic method. Journal of Financial Management of Property and Construction, v.22, n. 1, p., 37-61, 2017.

The effects of business environments on corporate strategies and performance 
of construction organisations. In: Procs 29th Annual ARCOM Conference, 2-4 September 2013, Reading, UK, Association of Researchers in Construction Management. UK, 691-701, 2013.

PORTER, M. Estratégia Competitiva: Técnicas para análise de indústrias e da concorrência. 7. ed. Rio de Janeiro: Campus, 1986.

SAMARTINI, A.L.S. Comparação entre métodos de mensuração da importância de atributos em produtos e serviços. GV - Pesquisa. São Paulo, 2006.

SANTOS, R. B. P.; PALADINI, E. P; JUNGlES, A. E. Proposta de indicadores de desempenho para uma empresa de consultoria na gestão da construção. In: ENCONTRO NACIONAL DE TECNOLOGIA DO AMBIENTE CONSTRUÍDO. n. 15, 2014. Anais... Maceió, Al, 1186-1195, 2014.

SOETANTO, R.; DAINTY, A.R.J. Integrating uncertainty management in strategic planning practice. Building a Sustainable Future. Construction Research Congress. Seattle, p. 309 319, 2009.

TANSEY, P.; MENG, X.; CLELAND, D. A critical review of response strategies adopted by construction companies during an economic recession. In: Smith, S.D and AhiagaDagbui, D.D (Eds) Procs 29th Annual ARCOM Conference, 2-4 September 2013, Reading, UK, Association of Researchers in Construction Management, 2013. p. 679- 689.

VIEIRA, S. Como elaborar questionários. São Paulo: Atlas, 2009.

ZAIDI, F.I; ZAWAWI, E.M.A.; NORDIN, R.M; AHNUAR, E.M. An empirical analysis of strategy implementation process and performance of construction companies. Conference Series: Earth and Environmental Science, n. 1, v. 117, 2018. 